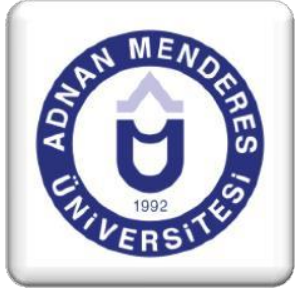

\title{
Habitus: Dini İnanç Habitusunun Oluşumu Üzerine Kavramsal Bir İnceleme
}

\author{
Ali BALTACI ${ }^{1}$
}

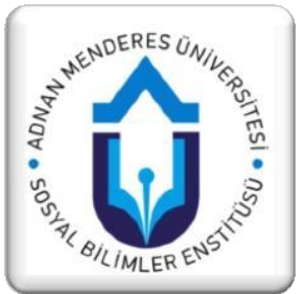

\section{ÖZET}

Habitus, bireylerin çevrelerindeki sosyal dünyayı algılama ve ona tepki verme biçimlerini düzenleyen bir somutlaştırılmış eğilimler sistemidir. Habitus kavramı, kültürel sermayenin fiziksel düzenlemesine, yaşam deneyimimiz nedeniyle sahip olduğumuz derin yerleşmiş alışkanlıklara, becerilere ve haklara atıfta bulunmaktadır. Bu haklar genelde benzer nitelikte (sosyal sınıf, din, milliyet, eğitim, meslek vb.), benzer kişilerle paylaşılır ve bireylerin toplumsallaştığı yaşam gerçeklerini, bireysel tecrübelerini ve nesnel imkânlarını yansıtır. Habitus sabit ya da kalıcı değildir ve beklenmedik durumlarda ya da uzun bir tarihsel dönemde değiştirilebilir. Dolayısıyla, habitus, kişisel tarihle birlikte grup kültürünü ve bugünkü toplumsal eylemi biçimlendirir. Din, hayatın diğer alanlarını içeren çok yönlü bir kavramdır. Dini inanç habitusu, kişinin yaşamında karşılaştığ farklı olasılıkların sonsuzluğunu belirleyen ve dört özelliğe sahip olan genel bir terimdir: Temelde öznenin bilinçsizliği, zamanla istikrarlı olması, toplumsal yapıların bir araya getirilmesi ve inanç alanında sürdürülen stratejik eylemlerden oluşur. Bu çalışma, yapı ve kurum arasındaki potansiyel çatışma alanları ve aktörlerin niyetleri ile bilinçliliği göz önüne alınarak, dini inanç habitusu kavramı ve kavramın verdiği cevaplara odaklanmaktadır. Bu bağlamda, kavramsal tarama modelinde tasarlanan bu çalışma, öncelikle habitus kavramına ve daha sonra dini inanç habitusu kavramına eğilmektedir. Çalışmanın asıl hedefi kuramsal bir kavram olan dini inanç habitusunu, özellikle atalet ve sosyal kuram perspektifi içinde daha ayrıntılı olarak irdelemek ve inancı analiz etme ve yorumlamanın farklı yönleri için tartışma alanları oluşturmaktır.

Anahtar Kelimeler: Habitus, Dini İnanç Habitusu, İnanç Alanı, Din Sermayesi

\section{Habitus: A Conceptual Study on the Formation of the Religious Faith Habitus}

\begin{abstract}
Habitus is a system of embodied dispositions, tendencies that organize the ways in which individuals perceive the social world around them and react to it. The concept of habitus refers to the physical embodiment of cultural capital, to the deeply ingrained habits, skills, and dispositions that we possess due to our life experiences. These dispositions are usually shared by people with a similar background (in terms of social class, religion, nationality, ethnicity, education, profession etc.), and reflects the lived reality to which individuals are socialized, their individual experience and objective opportunities. Thus, the habitus represents the way group culture with personal history and shapes social action in the present. Habitus is not fixed or permanent, and can be changed under unexpected situations or over a long historical period. Religion is a multidimensional concept which is an individual's journey through other aspects of life. Religious habitus is a generic term, which designates infinity of different possibilities and has four characteristics: It is mainly unconscious for the bearer, it is stable over time, it is the incorporation of social structures and it implies and enables strategic action within a faith field. This study focuses on the concept of religious faith habitus and the answers it provides given the potential areas of conflict between structure and agency and actors' intentions and unconsciousness. In this context, this study, designed as a conceptual review, primarily concentrates on habitus' concept and then the focuses on the religious faith habitus. The main aim of this study is a conceptual one: To further elaborate the concept of religious faith habitus, especially under the perspective of its inertia and social theory, and to discuss its usefulness for some aspects of analyzing and interpreting faith.
\end{abstract}

Keywords: Habitus, Religious Fatih Habitus, Faith Field, Religious Capital

1 Dr. Öğr. Üyesi, Muş Alparslan Üniversitesi, İslami İlimler Fakültesi, Felsefe ve Din Bilimleri Bölümü, baltaci7@gmail.com 


\section{Giriş}

Bilgi ve bilgiye ulaşma yollarının giderek çeşitlendiği günümüzden farklı olarak 1970'li y1llardan itibaren artan teknolojik gelişmeler ve sosyal değişimlerle birlikte sosyal bilimlerdeki geleneksel birikim gerilemeye başlamış, birey-toplum farklılaşması daha da görünür hale gelmiştir. İşlevselci yaklaşımın, sosyal olguların toplumsal bütünebakılarak anlaşılabileceğine ilişkin varsayımları, sosyal alanın birey veya minimalist döngüsünü göz ardı ederek, bütüncül düşünce yapısının düalite düşüncesini sürdürmüştür. Bu durum artan teknolojik değişim karşısında baskılanan sosyal olguların çağdaş bir bakış açısına evirilmesine ve yeni sosyal bilim akımlarının oluşmasına zemin hazırlamıştır. Tarihsel olarak Descartes, Marx, Weber, Durkheim, Simmel gibi pek çok sosyal bilimcinin ele aldığı düalite sorunu, Parsonsçu yapısal-işlevselci anlayışla genişleyerek, toplumsal gerçeklik düşüncesine dönüşmüştür (Grandjean, 1981). Ancak toplumsal alandaki bilginin, yine toplumsal alanda yer alan aktörler tarafından yeniden üretilebilir olması görüşünün temelinde yer alan eleştirel düşüncenin filizlenmesiyle tarihsel olarak süregelen düalite tartışmaları, bilginin toplumsal olarak üretimi özeline kaymıştır.

Bilginin sosyal açıdan inşa edilebilirliği görüşünü öne süren Pierre Bourdieu, Peter Berger ve Thomas Luckmann gibi sosyal bilimciler, toplumsal olguların yalnızca nesnel ya da öznel bir düzlemde algılanamayacağını, toplumsal alanın gerçekliğin diyalektik bir etkileşimi sonucunda yeniden üretildiğini savunmaktadırlar (Flanagan, 1993). Bourdieu, sembolik etkileşimci kuramları, toplumsal olgunun nesneleşen doğasını ihmal ettiği, yapısalişlevselcilik gibi kuramları da toplumsal olgunun öznelliğini önemsemediği gerekçesiyle eleştirmektedir. Öznelci ve Nesnelci oluşumların herhangi biçimini içeren ve toplumsal olgular ile diyalektik süreçleri de kapsayan bir sosyal kuramın, toplumsal alanlar ile birey ve kurum ilişkilerini de ihmal etmesi söz konusu değildir (Lau, 2004). Bourdieu'nun sosyal olguyu açıklamak üzere kurguladığı kavramın kuramsal zemini, özne ve nesne arasında süren bir ilişkisel paradigmaya dönüşür. Tek taraflı bakış açılarının yetersizliğini vurgulayan Bourdieu, sosyal olguların farklı ve kaotik ilişkisel desenlerle açıklanması gerektiğine inanmaktadır (Bourdieu, 1990b). Bu çalışmanın ana konusu olan habitusun, alan, illusio ve oyun kavramları olmaksızın tanımlanmasının güç olması, Bourdieu'nun kaotik ilişkisel desenlerinin anlaşılmasının zorunluluğunu ortaya koymaktadır. Bununla birlikte habitus kavramında yer alan yapısal ve işlevselci kuramsal zeminin özellikle Mead'ci benlik ve kimlik tartışmaları ve Schutz ve Husserl'ci fenomenolojik yaklaşım ile şekillendiği belirlenebilir.

Dini inançlar, kişinin yaşantısından ayrı olarak gelişen ve tüm yaşantıyı etkileyen bir olgudur. Kişinin dini inanç ve etkinlikleri, onun sosyal çevresi ile ilişki içindedir ve sosyal çevre, kişinin doğumundan itibaren tüm yaşamını şekillendirmektedir. Algılanan toplumsal gerçekliğin sosyal koşullar, alışkanlıklar veya rutinler aracılığıyla inşa edildiği varsayımına dayanan habitus kavramı, öncelikle Pierre Bourdieu'nun kavramsal savunuları eşliğinde incelenecek ve sonrasında habitus kavramının, dini inanç olgusuna etkilerinin izahı yapılmaya çalışılacaktır. Ayrıca çalışmada Bourdieu'nun kavramsal kurgusundaki habitus, alan, oyun ve doxa gibi kavramsal araçlar detaylandırılacak ve son olarak da kişide dini inanç olgusunun gelişimi irdelenecektir. Dini inanç kavramına ilişkin kuramsal bir altyapı oluşturma çabasıyla üretilen bu çalışmada dini inanç ve habitus kavramlarının etkileşimleri, benzerlikleri ve farklılıkları da ele almayı amaçlamaktadır. Bu bağlamda kavramsal tarama modelinde desenlenen çalışma Bourdieu'nun kavramsal birikiminin, toplumsal yapıyı anlamada daha belirleyici olduğu varsayımına dayanmakta ve habitus ile dini inanç kavramlarını Bourdieu'cu bir gelenekle ele almaktadır. 


\section{Kavramsal Olușumu Anlamak}

Kökenleri Platon ile Aristoteles geleneğine dayanan ve Durkheim ve Weber gibi sosyal bilimcilerle belirginleşen nesnelcilik ve öznelcilik kavramları, sosyal kuramları ve çeşitli yöntembilimsel paradigmaları etkilemiştir (Arthur, Hall ve Lawrence, 1989). Durkheim'in kuramsal söyleminde yer alan toplumsal bir sorunun yine toplumsal bir nedeni olabileceği anlayışı ile Weber'in toplumsal sorunu birey ve eylem temelli açıklama biçimi, sosyal kuramdaki esas düalizmin ifadesidir (Egerton ve Halsey, 1993). Durkheim'in toplumsal olguya yaklaşımı sosyal kuramların yapı merkezli doğasını etkilemiş ve hâkim paradigma haline gelmiştir. Toplumsal olgunun yine toplumsal nedenleri ile açıklanabileceği görüşü, Parsons'un sosyal sistem kuramında ve Giddens'ın 'ortodoks konsensüs' kavramlarında işlevsel bir forma kavuşmuştur (Giddens, 2013).

İşlevselcilik, toplumu anlamanın en etkili yolunu arayan ve toplumsal olguların nasıl analiz edilmesi gerektiğini belirleyen eleştirilerle çeşitlenmiştir. İşlevselci eleştiriler, birey ile yapı arasındaki öncelik sorunsalı ve toplumsal değişmenin kaynağı ile değişimin nasıl sağlanacağı yönündeki görüşlerle belirginleşmiştir (Parsons, 2013). İşlevselcilikle görünür hale gelen birey ve yap1 arasındaki ayrım, toplumda var olan kurumların toplumsal yapiların devamlılığına ve toplumsal alanın inşasına etki noktasında derinleşmiş ve tarihsel olarak süregelen düalite sorunu birey-yapı, özne-nesne, makro-mikro ve pozitivizm-hermeneutik bağlamında tartışmalara yol açmıştır (Robbins, 2005). Bu tartışmalar, sosyal kuramların toplumsal olguları anlama noktasında kutuplaşmasına yol açmıştır. Bu açıdan Bourdieu, sosyal kuramlardaki farklılıkları birleştirme amacıyla özne-nesne, birey-toplum, yapı-fail, makro-mikro, pozitivizm-hermeneutik gibi düal kavramların toplumsal olguyu anlamada eksiklikler içerdiğini ve düal ayrımların belirli bir düzlemde yeniden kavramsallaştırılmasına ihtiyaç olduğunu bildirmektedir (Bourdieu, 1984). Bourdieu, düaliteyi, sanal bir sorunlar zinciri veya körleştirici bir 1şık huzmesi olarak görmektedir. Dolayısıyla sanal sorunlardan uzak bir toplumsal anlama sahip olmak, günümüz toplumsal olgularını daha gerçekçi anlamaya salık verecektir (Bourdieu, 1977). Habitus kavramının kökenlerinde belirli bir düalist etki görülür. Habitusun kökenlerinde yer alan düalist etkileşimler bir sonraki bölümün tartışma konusudur.

\subsection{Düalitenin Formları: Nesnelciliğe karşı Öznelcilik}

Bourdieu'ya göre sosyal bilimlerin nesnesi: toplumsal olgunun yöneliminin anlaşılması ve toplumsalın bireylerde inşa edilmesiyle ortaya çıkan dayanıklı ve aktarılabilir algı, beğeni ve eylem sistemleri olan öznelcilik ile toplumsal olguların, fiziksel nesneleri yarı-gerçekliğine sahip olan mekanizmalar veya şeylerde inşası olan, nesnelciliktir (Bourdieu, 1984). Öznel ve nesnel inşayı rasyonelleştiren bu görüş, aynı zamanda uygulamalı rasyonalizmin, sosyal bilimlerin belirli ve değişmez kuralları temelinde yapılandığ 1 ve bunun anlaşılmasının belirli bazı modeller üzerinden gerçekleştirilebileceği (nesnellik) düşüncesine de tezatlık oluşturmaktadır. Benzer şekilde öznelci düşüncenin tekil çözümlemelerine karş1 olan Bourdieu, öznelciliğin, tıpkı nesnelcilikte olduğu gibi, toplumsal gerçekliğin yalnızca bir bölümünü açıklayabileceğini düşünmektedir.

Nesnelci yaklaşımlar, toplumun mekanik yapılarına odaklanmakta ve bireyi önemsememektedir (Burt, 1992). Bununla birlikte Durkheim'in “şey”leştirme olarak tanımladığı ve şey'lerin denetlenebildiği, öngörülebilir ve açık tanımlamalarının yapılabildiği, toplumun mekanik düzen temelinde anlaşılabileceğine ilişkin hipotezler, nesnelliğin kavramsal perspektifini oluşturur. Bu açıdan nesnel perspektifin temel sorunu, bu mekanik düzeni oluşturacak temel ilkelerin belirlenememesi ve toplumsal yapıları da şey’leştirme eğilimi göstermesidir (Benevolo ve Ipsen, 1995). Şey’leştirilen bir toplumun 
gerçeklik tezahürünün, standardize edilmiş veri formaları ve anketler gibi nicel ölçümlerle belirlenebileceği düşüncesi, yalnızca mekanik yapıları değil, aynı zamanda bireyleri de toplumsal gerçekliğe eklemleme çabasından ileri gitmemektedir. Nicel araştırmanın sunduğu ölçme araçlarıyla elde edilen nesnel veriler, zaten nesnel olan toplumsal yapının bilgisine nicel olarak ulaşılmasını sağlarken, toplumsal gerçekliğe ilişkin nitel bir veri sunmazlar (Dore, 2004).

Öznelcilik ise sembolik etkileşimcilik, fenomenoloji ve hermeneutik gibi kalitatif (nitel) paradigmalara yönelmekte ve toplumsal gerçekliği birey temelli bir formda ele almaktadır (Crossley, 2001). Başka bir deyişle öznelcilik, nesnelciliğin aksine, toplumsal gerçekliğin, özne ve öznenin eylemleri ile eylemin metodolojisi üzerinden anlaşılabileceği görüşüne dayanmaktadır. Toplumsal gerçeklik, aktörlerin sürekli eylem ve üretim-yeniden üretimiyle oluşur. Aktör, gerçekliğin yaratımında asli bir role sahiptir ve onun rol takımı içindeki faaliyetleri, aynı zamanda nesnel yapıyı da üretir (Parsons, 2013). Bu düşünceye karşı çıkan Bourdieu (1990a), toplumsal yapıları, bireylerin edim ve stratejilerinin basit bir ürünü olarak görmektedir. Bu düşün sisteminde aktör, yorumlayıcı bir yaratım içindedir ve aktörün, bilinçli olmakla birlikte, edimleriyle ürettiği ya da karşı koyduğu nesnel yapıların nasıl olup da varlıklarını devam ettirdiğine ilişkin sorunlar bulunmaktadır (Crossley, 2003). Bourdieu (1987), bir fail bir edimde bulunurken, bu ediminin sonucunda nesnel yapıyı üretmesinin anlaşılabilir olduğunu; buna karşın aktörün karşı çıabileceği nesnel yapılar olabileceğini ve bu nesnel yapının söz konusu aktörün karşı koyan edimine rağmen nasıl devamlılık gösterdiğini açıklayamadığını ileri sürmektedir. Bourdieu'ye göre (1990a) toplumsal gerçekliği anlamada yaşanan çıkmaz, bir taraftan toplumun bireyden çok önce var olan nesnel yapısının ve unsurlarının, diğer taraftan ise nesnel yapının üretilmesi ve yenidenüretilmesinde bireyin eyleminin önemine dikkat çekerek aşılabilir. Söz konusu düalite sorunu, nesnelleşmiş, yani zaman içinde şeyler, makineler, binalar, anıtlar, kitaplar, kuramlar, gelenek ve görenekler, toplumsal adetler, hukuk, dini inançlar vb. içinde biriken gerçekliğin ve habitus biçiminde beliren bireysel gerçekliğin birleşmesi ile çözümlenebilir. İlerleyen bölümde habitus kavramına 1şık tutan temel kavramlar tartışlacaktır.

\subsection{Valhalla ${ }^{2}$ ya da Toplumsal Gerçekliğin Yaratıcı Coğrafyası}

Elias'ın 'gerilim alanı' (1978), Habermas'ın Husserl'den aldığı 'yaşam dünyası' (1991) ve Chomsky'nin 'karşıtlıklar arenası' (2014) olarak tasvir ettiği alan, toplumda süregelen güç mücadelesi ve egemen tahakkümün sürdürülmesi için tarafların sürekli mücadele içinde olduğu bir mücadele veya toplumsalın yaratılma arenasıdır. Başka bir deyişle toplumsal gerçekliğin yaratım merkezi olan alan, güç ve sınıf ilişkilerinin karşılıklı olarak etkileşime girdiği, gücü elde etmek için gerçekleştirilen ve tarihsel olarak biçim değiştiren bir mücadelenin söz konusu olduğu ve kazanan tarafın sürekli değiştiği farklı ve çok boyutlu konumlardır (Iellatchitch, Mayrhofer ve Meyer, 2003). Gücün belirleyici karakteri ve mücadelenin sergileniş biçimleri, alan kavramının kendine has bir karakteristiğinin, gelenek, norm, kural ve değerlerinin olmasını gerektirmektedir (Knights ve Morgan, 1990). Bu kural ve değerler, aktörlerin (Bourdieu'ya göre oyuncular), genellikle farkına varamadıkları, açıklamakta zorlandıkları ancak eylem dizgesine ve pratiğine hâkim oldukları, çoğu kez içgüdüsel rol takımlarıdır (Bourdieu, 1986). Bu noktada sıradan veya kendiliğinden gelişen bir içgüdüsellik söz konusu değildir. Bourdieu'nun 'oyun' olarak metaforlaştırdığı bu durum, alandaki bireylerin birer oyuncu olması ve oyunu kurallarına uygun oynama çabası içinde oldukları düşüncesine dayanmaktadır (Bourdieu, 1990b). Belirli ödülleri elde etmek ve

\footnotetext{
2 İskandinav mitolojisinde insanların gerçeklikle karşılaştıkları, geniş bir alandır.
} 
cezalardan kaçınmak ekseninde şekillenen oyun, oynayan tarafların çeşitli kuralları karşılıklı olarak kabul etmesiyle sürdürülebilir. Karşılıklı kabul edilen bu kurallar, örtük bir mutabakat zeminidir ve bu durum Bourdieu'nun 'doxa' ${ }^{3}$ olarak kavramsallaştırdığı ön kabullerin bir tezahürüdür (Bourdieu, 1988). Alan ve oyun birbirinden farklı iki kavramdır ve alan, oyun kurallarının sergilendiği soyut bir coğrafi mekânı temsil edebildiği gibi, oyundan faklı olarak alan kavramının temel bir yasası ve kuralları bulunmaktadır (Lodge, 1995). Oyuna sadece taraflar hükmedebilir ve klasik oyun algısında bulunan ve oyunun kurallarını belirleyen hakemlik veya diğer arabulucu kurumların yer almadığı bir ilişki biçimine sahiptir. Oyuna giren tarafların karşılaşma zemini olan alana ilişkin düzenlemeler, sansürler, bask1 ve tahakküm durumu, ödül ve cezalar olsa da bu araçlar, önceden bilinmek veya öğrenilmek zorunda değildir (Barley, 1989; Higgins, 2001).

Toplumsal gerçekliğin bir yaratımı olan habitusun gözlemlendiği, eyleme dönüştüğü veya etkilerinin hissedildiği toplumsal ortam da alan kavramıyla açıklanmaktadır (Wacquant, 2014). Alan bir çatışma bağlamını da içermekte ve oyuncular arasında süregelen bir mücadelenin nesnesi de olmaktadır. Bu mücadele belirli sermaye formlarına ulaşmayı ve onları kontrol etmeyi de amaçlamaktadır (Chudzikowski ve Mayrhofer, 2011). Sermaye, oyuncuların sahip olduğu maddi veya manevi bilgi ve değerler bütünüdür (Lau, 2004). Bourdieu (1990b), alanlar içinde ekonomik, toplumsal, dini, kültürel ve simgesel sermaye türlerinin olduğunu ve sermayenin farklılaşmış biçimlerinin, alanın da farklılaşmasına yol açtı̆̆ını bildirmektedir. Yani ne kadar sermaye biçimi varsa, o kadar çeşitli alandan söz edilmektedir. Her alana etki eden farklı bir sermaye biçimi olabileceği gibi, sahip olunan sermayenin de etkilediği çeşitli ve çok sayıda alan olabilir (Suutari ve Mäkelä, 2007). Sermaye kendi bağlamında uyumlu ve dengeli olursa alanları o derece fazla etkilemektedir. Alan ve sermaye biçimleri arasında süregiden bir ilişkisellik söz konusudur (Bourdieu, 1990a). Örneğin bir veterinerin hayvan hastanesinde görev yapmasında oluşacak toplumsal üretim, aynı kişinin bir kadın doğum hastanesinde görev yapmasıyla bir toplumsal kaosa dönüşecektir. Bu dolayımda veterinerlik bilgisine dayalı sermayenin avantajı, o bilginin kullanılabileceği alanın varlığına bağlı olmaktadır.

Bourdieu'ye göre (1984), alanda yer alan kişi belirli bir güce sahip olmak istemekte ve alana dışarıdan müdahale edecek diğer oyuncuları engelleme eğiliminde olmaktadır. Diğer bir deyişle alandaki kişi, alandaki gücünü, egemenliğini ya da varlığını sürdürmek için alana dışardan yapılacak müdahaleleri veya giriş denemelerini engellemeye ya da alanın kurallarını kendisine göre belirlemeye çalışarak, alandaki tahakkümünü veya hâkimiyetini sağlama almaya çalışmaktadır. Bu durum alanın içindekilerle dışındakiler arasındaki bir mücadelenin varlığına işaret etmekte ve sermayenin sürekli korunması ve hatta geliştirilmesi gerekli bir kavram olduğuna vurgu yapmaktadır (Nora, 2004). Alanda herhangi bir oyunun içine dâhil olmuş ve üretime katılmış olan fail, alana yeni girmek isteyen başka bir failin inşa ve temsillerine karşı çıkmakta ve bu eski ile yeni arasındaki bu mücadele gerçekte oyuncuların temsil karakterinin, yaratı ve inşaların çatışması olarak dikkat çekmektedir (Chudzikowski ve Mayrhofer, 2011).

Alandaki mücadelenin biçimi, araçları veya yöntemleri, alanın yapısıyla ilişkili olarak

\footnotetext{
3 Doxa kavramının kaynă̆ı, Sokrates öncesi ilk felsefe metinleridir. Yunanca "kanaat" anlamına gelen doxa, Parmenides'in felsefesinde gerçekliğin bir bölümüne veya genel olarak varlığa dair çarpık ve yanlış kanaat demektir. Pierre Bourdieu doxa'yı toplumda yerleşik hâkim kanaatler bütünü olarak ele alır. Toplumun her alanında (ekonomi alanı, sanat alanı, siyaset alanı vs.), o alanın işlerliğini sağlayan ve alana katılanları alanın kurallarına uygun eylemeye sevk eden doxa'dır. Doxa alanın yapısallığını toplumsal faillerin gözünde normal ve doğal kılarak meşrulaştırır. Böylelikle doxa etkisi altındaki katılımcılar, alandaki örtük tahakküm ilişkilerini ve eşitsizlikleri yeniden üretir (Bourdieu, 1997).
} 
farkl11ık gösterse de mücadele düşüncesi ve pratikleri değişmemektedir. Alanda süregelen mücadele özünde, eskilerle yani alanda önceden bulunan ve sermayeye sahip olan birey, sınıf veya gruplarla yeniler, yani sonradan alana nüfuz etmeye çalışan birey, sınıf ve gruplar arasındadır (Dumais, 2002). Tarihsel olarak alanda eskiden beri varlığını sürdüren sermaye sahiplerinin, yeni oyuncular karşısında savunmacı bir tavır içinde oldukları, yeni oyuncuların ise sermayeye ve bu dolayımda alana talip olmaları sebebiyle saldırgan ve yıkıcı bir tavır sergileyecekleri bilinmektedir (Mayrhofer vd., 2004a). Žižek'in (2009) 'istila' metaforuyla açıkladığı bu duruma göre alandakiler, olması gereken düzenin zaten içinde bulunulan düzen olduğunu savunmakta ve dolayısıyla buna uygun bir doxa hali yaratmaktadır. Doxa, yukarıda tanımlandığı üzere hâkim görüş, egemenin bakış açısı, mutlak gerçeklik, üzerinde düşünülmeden kabul edilen görüştür (Bourdieu, 1988). Alana girme niyetinde olan yeniler ise, söz konusu doxanın, imha edilmesi gereken sanal bir durum olduğunu savunmakta ve içinde bulunulan düzenin, kendilerince yaratılacağına inanılan düzenden daha kötü olduğunu düşünmektedirler (Mayrhofer vd., 2002). Bu savunma ve saldırı hali, her iki grubun da alanın mücadeleye değer bir konumda olduğu yönündeki tahayyülünün gereğidir (Lau, 2004). Bu tahayyüller, oyuncuların karşılıklı olarak ve birbirinden farklı birtakım çıkarlar (illusio) ve stratejiler geliştirmesine de olanak tanımaktadır (Mayrhofer vd., 2004b). Bourdieu (1990a) oyunun içinde yer alan (eskiler) veya oyuna dâhil olmaya çalışan oyuncuların (yeniler), alanda uyguladığı koruma, izleme ve alt üst etme gibi çeşitli stratejiler geliştirebileceğini savunmaktadır.

Alanda egemen olma ve bunu sürdürme hali, oyuncuların koruma, alt-üst etme ve izleme gibi belirli stratejileri kullanılmasını gerektirir (Nora, 2004). Koruma stratejisi, alanda egemen konumda olan birey ve gruplarca benimsenmektedir. Egemen birey, grup veya sınıflar var olan iktidarlarını sürdürmek ve kendi statükolarını savunmak amacıyla dışarıdan kendi hâkimiyet alanlarına müdahil olmak isteyenlere karşı korumacı tavırlar geliştirirler (Barley, 1989) ve var olan konumlarını korumaya çalışırlar (Dumais, 2002). Yeni gelenlerin, farklılık, çeşitlenme ve değişim talebine karşı var olan durumu muhafaza etme çabası, her türlü sert-radikal çıkışa karşı hazırlıklıdır (Chomsky, 2014). İzleme ise alana yeni giren ya da girmeye çalışanlar tarafından benimsenen bir stratejidir (Lau, 2004) ve alanı yakın gözetim altına alarak egemenlerin iktidar formlarını örtük bir biçimde denetleme amacı gütmektedir (Mayrhofer vd., 2004a). Alt-üst etme stratejisi, evrimsel dinamiklerin bir sonucudur ve genellikle radikal değişiklik talebinde bulunan birey ve grupların benimsediği ve alanda marjinal değişiklik oluşturma düşüncesi üzerine kuruludur (Crossley, 2003). Alt-üst etme, yeniden üretimin de esasını oluşturmaktadır.

Doxa ve illusio, habitus kavramını oluşturma sürecinde Bourdieu'nun ele aldığı alt kavramlardandır. Toplumsal gerçekliğin, göründüğü şekliyle algılanıp tecrübe edilmesi olarak tanımlanan doxa kavramı, değişmez bir inanç veya sabit ortak kabuller olarak algılandığında, alandaki yapının veya statükonun var olduğu şekliyle kabul edilmesidir (Mayrhofer vd., 2000). Üzerinde düşünülmeden, eleştirilmeden uyulan her kural ya da dikkate alınan her söylemin kökenlerinde doxa hali bulunmaktadır (Bourdieu, 1988). Doxa ayrıca, alanda egemen konumda olanların iktidarının ve bu dolayımda tahakkümün de sürmesine atıf yapmaktadır (Crossley, 2003). İllusio ise oyuna yoğunlaşmak, oyun tarafından ele geçirilmek, oyunun yapılana değdiğini sanmak, ya da daha sade bir dille ifade etmek gerekirse, oyun oynamaya değdiğini düşünmektir (Bourdieu, 1977). Bourdieu (1990b), illusio'yu yatırım ve çıkar ilişkileri bağlamında incelerken, illusio'nun doğal olmaktan çok evrimsel bir kavram olduğunu savunmaktadır. İllusio kavramı, evrimsel olarak gelişmiş ve zaman içinde çok yönlü bir yapıya ulaşmıştır. Bu noktada illusio, tek bir çıkarı kapsamamakta, farklı öznelerin çeşitli ve değişken çıkarları bağlamında değerlendirilmektedir (Žižek, 2009). İllusio'nun referans noktası olan çıkarlar, sosyal 
koşulların bir belirlemesi veya sosyal gerçekliğin tarihsel bir inşasıdır ve failin hangi sosyal koşullarda olduğunun belirlemektedir (Arthur, Hall ve Lawrence, 1989). Bu noktada oyuncu, aktör ya da fail, işgal ettiği statü ya da alana uygun olarak bir çıkar tanımı yapar ve kendi tahayyülü ile var ettiği gerçeklik içinde yaşar. Bourdieu (1989), alandaki bu çıkarların somutlaşmış yatkınlıklar derecesinde oldukları için fail tarafından içselleştirildiğini ve farkına varılmadığını savunmaktadır. Bourdieu'dan farklı olarak Benhabib (2002) ise çıkar kavramını "amaca yönelmişlik" olarak tanımlamakta ve çıkara dayalı her eylemin, araçsal hesaplamaları içeren bir eylem olduğunu ifade etmektedir.

Bourdieu'nun betimlediği habitus olgusunu açıklayan çıkar kavramı, pratik ve yatkınlığa bağlıdır ve genellikle faydacı çerçeveyle ilişkilendirilen amaca yönelmişliği içermemektedir (Burt, 1992). Toplumsal gerçekliğin tezahür ettiği nesnel koşullar içinde konumlanan çıkara yönelik eylem, bilinçli ya da akılcı bir hesaplamanın dışında, yatkınlıklara dayanır (Žižek, 2009). Sosyal olgular benzer şartlarda benzer sonuçlar vermeye meyilli olsalar da çoğu kez her durum bir öncekini anımsatmamakta ve eşsiz bir formda olabilmektedir. Pratikte mücadele durumunda yer alan birey, sinıf ve grupların, rasyonel bir hesaplama yapmasina olanak tanıyan yeterli zaman ve çok sayıda işlenmiş veri bulunmaz. Buna karşın failler çoğu durumda rastlantısal olarak eyleme geçer ve anlık olarak yapılması gerekenleri yaparlar. Zira benzer koşullara sürekli maruz kalmanın bir ürünü olan pratik aklın sezgilerine kendilerini bırakmakta ve sosyal alana ilişkin gereklilikleri önceden kestirmektedirler (Flanagan, 1993). Böylesi bir zeminde fail, kendi eylemine ilişkin çıkarları da algılama ve yarı bilinçli bir şekilde eylemlerine devam eder. Failin eylemleri veya deneyimlediği 'pratikler' gerek yatkınlıklar gerekse nesnel yapıların bir kesişmesi sonucunda belirmektedir. Pratikler bir taraftan nesnel olanı yeniden üretirken diğer taraftan habitus tarafindan da biçimlendirilmektedirler (Lodge, 1995; Robbins, 2005). Söz konusu diyalektik ilişki, her iki kavramı yeniden biçimlendirmekte ve Bourdieu'nun (1988) tanımladığı şekliyle pratik, habitus, alan ve sermayenin birleşiminden oluşmaktadır. Başka bir ifadeyle inanç ve eylemlerimiz, doğrudan alışkanlıklarımızdan oluşmamaktadır. İnanç ve eylemlerimiz, sosyal bir alanın içerisinde cereyan eden, kültürel değerlerimiz, kişisel seçimlerimiz ve toplumsal etkileşim gibi farklı gerçekliklerin bir bütünü olmaktadır. Benzer şekilde inanç ve eylemlerimiz, çoğu kez bireysel seçimlerimiz üzerindeki sosyal etkilere bağlı olarak oluşmaktadır. Mücadele ise toplumsal alanda var olma savaşı veya oyun oynama yeteneklerimizin oluştuğu doğaçlama süreçlerdir (Mayrfroher vd., 2004a).

\subsection{Habitus: Zorunluluğun Erdemine Seyahat}

Esasen Bourdieu'ya atfedilse de antik Yunan düşünürü Aristoteles ile ilişkilendirilen ve kavramsal temelleri Durkheim, Weber, Gehlen, Husserl, Schultz ve Veblen gibi sosyal bilimciler tarafından oluşturulan habitus, alışkanlık (habit) kelimesinden türetilmiştir (Giddens, 2013). Aristoteles, zaman içinde alışkanlıkların belirli yeteneklere dönüştügünü ve yeteneklerin de bireylerin mizacı olduğunu bildirmiş ve bu görüşünü 'ethics' (huy; iyelik) kavramı ile bütünleştirmiştir (Bernstein, 2003). Mauss'a göre habitus, Aristoteles'in 'sürekli yinelenen ve alışkanlık haline getirilmiş davranış biçimi' olarak kavramlaştırdığ 1 kullanımın aslında çok daha derin anlamlar içermekte ve yalnızca 'edinilmiş düşünce, davranış ya da beğeni kalıbı' olarak algılanmaması gerekmektedir (akt. Delamont ve Stephens, 2008). Merleau-Ponty, maddi yaşamın ve toplumsal ilişkilerin içinden çıkan değerler, zorunlu normlar, kurallar ve beklentilerin bir 'habitus' oluşturduğunu ve bireylerin öznel ve nesnel dünyayı bu gerçeklikte deneyimlediğini bildirmiştir (akt. Crossley, 2001).

Bourdieu'nun habitus kavramı, bireylerin toplumsal alanlara nüfuzu ile deneyimledikleri bilgi ve deneyim kazanımını vurgu yapmaktadır. Habitus, yalnızca bireysel bilgi ve deneyimler değil, aynı zamanda bir yapı ya da herhangi bir çevre veya toplumsal formasyon 
içindeki pratiği biçimlendiren varlık koşullarıdır (Delamont ve Stephens, 2008). Bireyin deneyimleri ve diğer pratikler habitus tarafindan şekillendirilebilir ve farklı nesnel yapıları da üretirler. $\mathrm{Bu}$ noktada oyuncular, var olan koşulları pratik olarak benimseyip etkinleştirmektedir (Crossley, 2013). Bu durum yeni bir sosyal çevreye girmeye çalışan kişinin içinde bulunduğu bağlama ve koşullara uyum sağlaması ve kendi gerçekliğini bu yeni durum üzerinden deneyimlemesidir. $\mathrm{Bu}$ açıdan habitus, çeşitli mekân ve koşullardaki toplumsal deneyimlerimizin bir sonucudur (Dore, 2004). Belirli durumlar ve tecrübelerimiz, dünyaya, bilgi ve kaynaklara yaklaşımımızı derinden etkiler. Habitus, geçmiş deneyimlerimize dayalı strateji üretici bir ilkedir olmakla birlikte, bireyin gerçekleştireceği eyleme öznel bir yön ve eğilim kazandırır (Dumais, 2002).

Habitus bir kişinin diğer kişilerden veya toplumsal kurumlardan neler istediği ve karş1lıklı ilişkilerinde hangi çıkarları sağlayabileceği konusundaki beklentilerini besleyen eğilimlere de atıf yapmaktadır (Giddens, 2013). Bir kişinin bir davranışı veya eylemi nasıl yapacağını bildiği, ancak bu davranışı neden yaptığını açıklayamadığı durumlar da habitus kavramı içinde değerlendirilmektedir (Lodge, 1995). Böylesi durumlar, kişinin sosyalleşme aşamalarına atıf yapar ve farklı durumlara göre farklı stratejiler geliştirdiği kabulünü yansıtır. Yani insanlar, içinde yaşadıkları toplumsal koşullardan yeni durumlar üretme yeteneğine ve eğilimine sahiptirler; üretim ve yeniden üretim bir zorunluluktur ve kişilerin bu stratejileri uygulamaktan başka şansları bulunmamaktadır. Kişinin içinde bulunduğu durumlardan yeni deneyimleri aracılığıyla üretimde bulunması habitus'u oluşturmaktadır.

Yapılan tanımlarda da habitusun nesnel ve öznel yanlarına yapılan bir vurguya sahip olduğu görülmektedir. Bir "tutumlar dizgesi" (Bourdieu, 1977) ve "insanın varoluşu ya da bedenleşmiş toplumsallık" (Bourdieu, 1990a) olarak habitus, dünyayı kendi algımıza göre var eden şeydir (Robbins, 2005). Bu açıdan toplumsal gerçeklik öznel ve nesnel bir üretimle iki biçimde var olmaktadır: İlki kendi içsel ve öznel algımızla şekillenen dünya (Crossley, 2013) ve ikincisi bizim dışımızda gerçekliğini bildiğimiz dünya (Wacquant, 2014). Ayrıca habitus, kendi gerçekliği ile temas ettiği ya da üretildiği toplumsal alanlarla etkileştiğinde Aristoteles'in 'balık ve su'4 metaforuna benzer şekilde davranabilir (Žižek, 2009).

Bourdieu'nun "zorunluluğun erdem haline gelmesi" (1990a) veya nesnel zorunlulukların bireysel kazanımı (1990b) olarak kavramsallaştırdığı habitus, toplumsal gerçekliğe nüfuz etme noktasında çeşitli stratejiler sunmaktadır. Bu stratejiler, bireyin içinde bulunduğu nesnel koşullarla bir uyum halindedirler (Lau, 2004). Dişsal olarak kurulan nesnel zorunluluğa maruz kalan birey, bunu içselleştirerek kendinden bir parça olarak görmeye başlar. Bir yandan bu nesnel şartları kabul ederek devamlılığını sağlarken diğer yandan da pratikler sayesinde bu durumun farklı bir şekle bürünmesini ya da yeniden üretilmesini sağlamaktadır (Giddens, 2013). Bu açıdan bağımsız ve yalıtılmış bir nesnel gerçeklik veya zorunluluğun olması mümkün değildir. Bourdieu'ye göre (1990b) nesnel zorunluluklar belirli ölçüde bask1 ve güce sahip olsa da bireyin hiçbir durumda müdahil olamayacağı bir duruma gönderme yapmaz. Birey, öznel eylem ve stratejileriyle alanlarda karşılaştığ durumlar karşısında yeni düzenliliklerin de temellerini atar. Böylece habitus, nesnel kültürel yapıların oluşumunda doğrudan bir etkiye sahip olur ve ürünü olduğu sosyal dünya ile gerçek bir etkileşime dönüşür (Suutari ve Mäkelä, 2007). Söz konusu etkileşim habitusun üretildiği nesnel koşulların düzenliliklerini de yeniden üretmektedir. Bu yeniden üretim, pratikler aracılığıyla bireylerin karşılaştıkları durumlara göre gerek eski deneyimlerinden gerekse yeni ve eşsiz stratejiler üretmesiyle gerçekleşir (Mayrhofer vd., 2002). Stratejilerin

\footnotetext{
${ }^{4}$ Aristoteles, su içerisindeki bir balığın suyun ağırlığını hissetmediğini, etrafindaki tüm dünyayı sudan ibaret saydığını, buna karşın su dışına çıkarıldığında yeni gerçekliği eskisinden ayırt edebildiğini ifade etmektedir.
} 
eşliğindeki her yeniden üretim, yeni bir durumsal tanımlamayı gerekli kılmakta, var olan durumun değiștiğini göstermektedir. Değișen durumun üstesinden gelebilmek ve uyumu gerçekleştirebilmek için de sahip olunan habitusta değişim gerçekleşir. Bu da habitusun sabit, değişmez bir yapıda olmadığı, var olan duruma uyum sağlamak için değişebildiği anlamına gelmektedir. Bu şekliyle habitus sürekli deneyime tabi tutulabilen ve deneyimlerle dönüşebilen bir eğilimler sistemidir (Crossley, 2013).

\section{Dini İnanç Habitusu: Zorunluluktan Doğan Yönelimler}

Dini inançlar bağlamında habitus, bireyin bağlamsal erişimi ve geçmiş deneyimleri üzerinde inşa edilen bir kapsamda incelenmektedir. Dini inançlar, bireyin, tüm ifade ve eylemlerinin kökeninde onun geçmiş deneyimleri ve içinde yaşadığı toplumun inanç unsurları olduğu ve bu tezahürlerin önceden biçimlendiren çeşitli kişisel şemalar topluluğu tarafından oluşturulduğu kabul edilmektedir (Iellatchitch, Mayrhofer ve Meyer, 2003). Bu kapsamda en kısa tabiriyle dini inanç habitusu, bireyin sahip olduğu sermayeyle toplumsal alanlara girmesi ve burada yer alan çeşitli aktör ve yapılarla etkileşerek ve yer yer mücadele ederek kendi dini inanışlarını oluşturması sürecidir (Mayrhofer vd., 2000). Dini inanç habitusu, kişinin özgür bir şekilde bir dine ilişkin inanmaya hazır olduğu seçim döneminden itibaren başlayan ve yaşamı sonlanıncaya kadar devam eden dinamik bir uyum sürecine de vurgu yapmaktadır (Lodge, 1995). Dini inanç habitusunu daha iyi kavramak için dini inanç alanları, din sermayesi gibi kavramların tartışılması yerinde olacaktır.

\subsection{Dini İnanç Alanları}

Bourdieu'ya göre (1988), sosyal alan, kuralları ve rolleri önceden belirlenmiş bir eylemi gerçekleştirmeye çalışan sermaye sahibi aktörlerin pozisyonlarını korumaya ve ilerletmeye çalıştıkları bir oyun alanı veya savaş alanını ifade etmektedir. Bu noktada aktörler, kendi konumlarını referans alarak bir konum ağı oluşturur ve diğer aktörleri de kontrol edebilecekleri ve içinde oldukları şartları koruyup geliştirebilecekleri çeşitli bireysel stratejiler geliştirirler (Bourdieu, 1990b). Aktörlerin kullanmak veya korumak zorunda olduğu kaynakların sınırlı olduğu bir ortamda doğal olarak mücadeleyi içermektedir (Lau, 2004). Dini inanç alanlarında kurallar, genellikle en baskın ve en değerli sermaye setine (bilgi birikimi) sahip aktörler veya yapıların (devlet vb.) tanımladığı şekliyle kabul edilir. Burada bahsedilen baskın veya değerli sermaye belirli koşullar altında dini inanç alanında bulunanların kabul ettiği ölçütler olup bazı durumlarda tekeli elinde bulunduran aktörlere de atıf yapmaktadır (Giddens, 2013). Dini inanç alanlarına girmek isteyen yeni aktörler ya belirlenmiş kurallara göre hareket etme veya kuralları yok sayarak kargaşa yaratma (entropi) eğilimindedirler. Söz konusu kargaşa yıkıcı değil, aksine yeni düzeni oluşturacak üretimleri sağlayıcı ölçüdedir (Bourdieu, 1977;1986). Dini inanç alanına yeni giren ve kendisini var etme çabasında olan aktörlerin temel güdüsü, alandaki var olan bilgiye aykırı ve yeni bir bilgiyi alana sunma çabasıdır. Örneğin dini inanç alanlarında yer alan tartışmalı konuların farklı biçimlerde dile getirilmesi, yeni ihtilaf alanlarına veya toplumda infiale neden olabilecek bilgilerin dini inanç alanlarına sunulması, dini inanç alanlarına yeni katılan bireylerin yaptığı eylemlerden bazılarıdır.

Dini inanç alanları, bir dine yönelik inanç ve ibadet gereklerinin belirlendiği, din adamları ve inananların karşı karşıya geldiği dinamik bir alan olmasının yanında, din adamlarının da gerek birbirleriyle ve gerek diğer kurumlarla (devlet ve uluslararası mekanizmalar vb.) karşılaştığı serbest piyasa koşullarına da vurgu yapmaktadır (Iellatchitch, Mayrhofer ve Meyer, 2003). Aktörler, dini inanç alanı içinde kendilerince konum almakta ve bu konumun sağladığ1 referans çerçevesinden hareket ederek bir ilişkiler ağı kurma eğiliminde olurlar. Çünkü dini inanç alanı statik bir mücadele alanı olmaktan çok, piyasa koşullarının hâkim 
olduğu dinamik bir yapıya sahiptir (Higgins, 2001) ve bu dolayımda hareket ve ilişki ağı oluşturmayan aktörler, diğer aktörler tarafından dini inanç alanının dışına itilirler (Grandjean, 1981). Bu nedenle dini inanç alanı içinde yer alan tüm aktörler hem kendilerini geliştirecek hem de yeni ilişki biçimleri oluşturabilecek bilgi, beceri ve yeteneklere veya çeşitli stratejilere sahip olmalıdır (Flanagan, 1993). Dini inanç alanında yer kapmak, gücü elinde bulundurmak ve konumunu korumak için en değerli sermaye setinin tanımladığ oyunun kurallarına göre hareket eden aktörler, bu sayede ilişki temelli ağların ve yeni dini inanç alanlarının oluşturulmasına da katkı sağlayacaktır (Bourdieu, 1977;1986).

Dini inanç alanları, dini inanışların gerekleri ve ibadet esaslarını belirlediği için, o dine inanan tüm bireylerin içinde hareket ettikleri toplumsal bağlamdır (Bernstein, 2003). Gerek din adamı gerekse inanan konumunda alanda yer alan ve alana yeni girme eğiliminde olan aktörlerin, önceden belirlenmiş kural dizgisine uyum sağlamak için özellikli bir donanıma (eğitim, hitabet yeteneği vb.) sahip olmaları gereklidir (Benevolo ve Ipsen, 1995). Bu kişilerin elde ettikleri firsatlar veya kendilerine sağladıkları pozisyonlardaki yerlerini korumaya veya geliştirmeye çalıştıkları sıklıkla görülür (Egerton ve Halsey, 1993). Bu eğilim inananların sürekli olarak dinamik kalmasını ve alanda kendi çıkarına en iyi olan inançların peşinde koşmasını sağlarken, din adamı için daha nitelikli inananlarla karşılaşma imkânı sunmaktadır (Barley, 1989). Dini inanç alanlarının böylesi dinamik bir yapıya sahip olması, alanda belirlenen kuralların, her yeni aktör tarafından içselleştirilmesi ve giderek yeni kuralların da eklemlenmesiyle güçlendirilip daha nitelikli aktörlerin alanda yer almasını sağlayacak şekilde biçimlendirilmesiyle sağlanmaktadır (Crossley, 2013). Yani dini inanç alanları, evrimsel bir süzgeç görevi görerek en değerli sermayeye sahip aktörlerin alanda olmasını sağlayacak şekilde sınırlandırılmış bir kurallar dizgesine sahiptir (Mayrhofer vd., 2004). Bu açıdan piyasa koşullarının egemen olduğu dini inanç alanları, vahşi doğaya benzemekte ve her ikisinde de yalnızca en iyiler yaşamını sürdürmektedirler. Bu durum, iş ile zaman arasındaki odak kaymasını yansitmaktadır (Duberley ve Cohen, 2010). Yani dini inanç alanında yer alan aktörlerin sahip olduğu inancın kendisi bir alan değildir. Bu durum, bir alanda belirli bir süre içinde oluşturulmuş sermaye biçimidir ve dini sermaye ilgili çabalardan kaynaklanan pozisyon sıralamalarıdır. Aslında dini inanç, bir inananın belirli bir inanç gereğini gerçekleştirdikten sonra kazandığı tecrübeler ve bu kazanımları yeni dini gerekleri gerçekleştirme becerisidir. Bu beceri dini inanç alanlarında aktörün, diğerlerinden farklı olmasını sağlar ki buna da dini inanç deneyimi denilmektedir (Arthur, Hall ve Lawrence, 1989). Dini inanç deneyimi, inanç alanlarındaki mücadeleden başarıyla çıkan aktörlerin kazanımlarının bir toplamıdır (Lau, 2004).

Dini inanç alanı, din adamlarına özel sektörde ve kamu kurumlarında sağlanan istihdam olanakları ile serbest çalışma ya da profesyonellik arasında değişen tasarımlara sahiptir. Söz konusu alan tasarımları, aktörün içinde bulunduğu bağlama göre çeşitlilik göstermekte ve genellikle aktörün sahip olduğu sermayeye göre belirlenmektedir (Vilhjálmsdóttir ve Arnkelsson, 2013). Bununla birlikte bir ülkede kamu kurumlarınca sağlanan dini inanç hizmetler, başka bir ülkede özel sektör veya serbest çalışan profesyoneller tarafından sunulmakta ve bu durum istihdam alanlarının da farklı kurgulanması gerektiğine işaret etmektedir. Liberalizmin bir gereği olarak serbest piyasa koşulları içinde yer alan dini inaanç alanları, genellikle belirli bir iliş̧kiler ağı şeklinde tasarlanmıştır. Bu ilişkiler ağında, İslam ve Ortodoks Hristiyanlıkta olduğu gibi dini inanışların gerektirdiği nitelikte din adamlarının yetiştirilmesi veya din adamının niteliklerine göre dini inançların oluşturulması (Mormon ve Evangelist yönelimler vb.) söz konusu olsa da geçmişte ihtiyaç duyulan ancak zaman içinde geçerliğini yitiren inanışların ve din adamlarının da farklılaştırıldığı görülmektedir (Hristiyan Cizvit inanışı vb.) (Savickas, 2005). Örneğin son üç asırdır Hristiyan inancını yeni keşfedilen kıtalara veya ele geçirilen bölgelere yayma eğiliminde olan Hristiyan Katolik Kilisenin, 
zaman içinde gelişen sosyal ve teknolojik değişimlere ve yeni toplumsal düzene ayak uydurduğu ve yayılmacı tutumunu, zamanın ruhuna uygun bir şekilde yeni strateji ve politikalarla geliştirdiği gözlenmektedir. Özellikle Hristiyanlıkta karşılaşılan bu durum, dini inanç alanlarında sabit kuralların ve politikaların olmayabileceğini, zaman içinde dinamik ve radikal kuralların eskilerinin yerini alabileceğini göstermektedir (Mayrhofer vd., 2000; Iellatchitch, Mayrhofer ve Meyer, 2003).

\subsection{Din Sermayesi}

Din sermayesi, gerçekte dini inanç alanlarında mücadele eden tüm aktörlerin sahip oldukları bütün kazanımlarıdır (Jokinen, Brewster ve Suutari, 2008). Bu açıdan sermaye, aktörün bir toplumsal alana katılımını ve bu alan içerisinde rekabetin getirdiği özel kazançlara ulaşmayı mümkün kılan kaynaklardır (Suutari ve Mäkelä, 2007). Başka bir deyişle dini inançların oluşum sürecinden itibaren kişiyi destekleyen deneyim, anı ve toplumsal ilişkilerin bütünüdür. Din sermayesi, sosyal sermayenin farklılaşmış bir türü olarak değerlendirilmekte, kurumsallaşmış ve genellikle uzun ömürlü iletişim ağına atıf yapması nedeniyle, bireyin veya grubun bir dine ilişkin tüm kazanımlarının toplamı olarak tanımlanmaktadır (Duberley ve Cohen, 2010). Yani din sermayesi, inananların dini inanç alanlarına erişmesinde ona fayda ve çıkar sağlayan tüm kaynaklardır.

Din sermayesinin kazanılması ve korunmasında öncelikle kişinin yaşam alanını oluşturan habitusun belirlediği eğilimler ile bireyin geçmişinin bir parçası olan (aile, okul hayatı, arkadaşlık vb.) eğilimler önemlidir. Kişinin içinde yer aldığı sosyal gerçeklik, onun dini sermaye eğilimlerini etkilemekte ve aynı zamanda dini sınıfları birbirinden ayırarak mevcut yapıların korunmasını sağlamaktadır (Mayrhofer vd., 2004b). Örneğin bir dinin özel bir yorumu olan tarikatlar, cemaat ya da inanç grupları gibi belirli dini sınıfların tekelinde olan bilgi ve metalar, kendi gerçekliğini ve kendi sosyal sınıflarını oluşturmakta ve bu bilgi ve metalara ulaşamayacak durumda olanlardan korunmaktadır. Din eksenli sosyal sınıfın üst basamaklarında olanlar ile alt basamaklarında olanlar arasında da benzer bir ayrıklık sürekli üretilerek tarikat, cemaat ya da inanç grupları içindeki sınıflar arası sınırlar sermaye aracılığıyla belirginleştirilmektedir (Savickas, 2005).

Dini inanç alanlarında aktörler tarafından elde edilen dini sermaye türleri azalıp artabilen miktarlarına, pratikler üzerinden kullanım şekillerine, bir türden diğerine tahvil edilebilirliklerine göre farklılaşan etkilere sahiptir (Bernstein, 2003). Aktörlerin sosyal bağlantıları ve dini grup üyelikleri üzerinden sahip olduğu sermaye, satın alma gücü, eğitim, dil alışkanlıkları, beğeni yargısı; bunların hepsi farklı alanlarda diğer eyleyicilerle mücadele içinde birer tahakküm kozuna dönüştürülebilir. Ayrıca aktörlerin edindikleri eğilimler sistemi onların toplumda işgal ettikleri konuma ve özel sermaye donanımlarına da bağlı olmaktadır. Bourdieu'ya göre (1986) sermaye: ekonomik, sosyal, kültürel (bilgi) ve simgesel sermaye olarak isimlendirilen farklı formlara sahiptir. Ekonomik sermaye, her şeyden önce, bir nesilden diğerine miras kalan genel, kaynağı belirsiz, çok amaçlı kullanılabilen veya harcanabilen para veya diğer ekonomik araçlardır (Grandjean, 1981). Ekonomik sermaye kapsamındaki araçlar, sosyal, kültürel ve simgesel sermayeye daha kolay ve verimli bir şekilde dönüştürülebilirler. Sosyal sermaye, kişilerin karşılıklı olarak birbirleriyle ilişkiler kurma, sosyal bağlantılara dayalı kaynaklar ve grup veya sınıf üyeliği arasındaki ilişkileri kapsar (Giddens, 2013). Sosyal sermaye, bireyin toplum içerisinde tanıdığı ve zamanı geldiğinde desteklerini alabileceği, güvendiği fertler ağına atıf yapar. Dini inanç alanlarında en çok kullanılan sermaye türü olan sosyal sermaye, aktörler için faydalıdır, çünkü aktörler, alanlarla diğer aktörlerle olan ilişkilerini ve hareket durumlarını sosyal sermaye düzeylerine göre oluşturabilirler (Duberley ve Cohen, 2010). Aktörün dini inanç alanlarına nüfuz etmesi ve yeni ilişkiler kurması, sosyal sermayesini kullanma gücü ile ilişkilidir. Ayrıca sosyal 
sermaye akrabalık ilişkilerinden doğan etkileşimleri ve bireyin ailesinden gelen dini grup üyelikleri gibi süreçleri de kapsamaktadır.

Kültürel veya bilgi sermayesi ise toplumda yüksek olduğu düşünülen değerler hakkında bilgi sahibi olmaktır (Bourdieu, 1986). Kültürel sermaye kapsamında inanç alanlarına yeni girecek aktörlerin sahip oldukları diploma, sertifika veya mezun oldukları okul önem arz etmektedir. Kültürel sermaye dini ve sosyal sınıfların oluşturulması oldukça etkili bir araç olmakla beraber özellikle dini inanç alanlarında statü kazanma ve sosyal konumların belirlenmesinde başat rol üstlenmektedir (Jokinen, Brewster ve Suutari, 2008). Bu noktada kültürel sermaye liberal ekonominin gereklerine uygun bir şekilde piyasa şartlarına uyum sağlar ve inşa edilen toplumsal gerçekliğin yapısına göre "dini sermaye", "bürokratik sermaye", "politik sermaye", "eğitimsel sermaye" gibi farklı formlara bürünebilir (Wacquant, 2014).

Dini inanç alanlarında karşılaşılan kültürel sermaye Bourdieu'ye göre üç şekilde görünmektedir (1990a): "Bedenselleşmiş, nesnelleşmiş ve kuramsallaşmış". Eğitim veya diğer yollarla bir dine ilişkin edinilmiş biçimsel bilgiler bedenselleşen kültürel sermayeyi oluşturur (Vilhjálmsdóttir ve Arnkelsson, 2013). Kültürel sermayenin bedenleşen formunu saptamak nispeten kolaydır: bir kişinin konuşma veya dilekçe yazma becerisinden hareketle çocukluktan başlayarak içinde bulunduğu sosyal sınıf, ailesinin sosyal statüsü, öğrenilen anadil alışkanlıkları, yazma becerisi gibi özellikler belirlenebilir. Nesnelleşen kültürel sermayeye örnek olarak kitaplar, resimler, vb. gibi, üretim için öznelleşmiş nesnelerin formu verilebilir (Bourdieu, 1990b). Dini sermayenin bu biçimi zorunlu olmayan ancak aktöre değer katan bir özelliktedir. Örneğin din adamının arkeoloji, felsefe, sinema veya mimari hakkında ileri düzey bilgi sahibi olması inanları etkileyebilir ya da bu nesnel bilgiler din adamına farklı çalışma imkânları sunabilir. Kuramsallaşan durumda ise gerçekte kurulmuş olan kültürel sermayeden nispeten bağımsız olan akademik derece ve unvanlar ile kurumsallaşmış dini sermaye söz konusudur (Nora, 2004). Kültürel sermayenin üçüncü hali, örneğin bir din adamının sadece kendi alanında değil çok farklı alanlarda da bilgisi olabileceği öngörüsünü de içermektedir. Sembolik sermaye ise dini inanç alanında bireyin algılanış biçimi veya bireyin kendisi ile alakalı olan görünüş, onur, prestij, duruş ve konuşma gibi özellikleridir (Mayrhofer vd., 2002). Habitusun belirleyicisi olan sembolik sermaye, algılanan kültürel miras, dini gereklilikler ve sosyal gerçekliğe göre kişilerin davranış ve eylemlerinin değişmesidir. Sembolik sermaye geçmişten gelen kazanımlarla oluşmakta ve kültürel sermaye ile birleşerek habitusu oluşturmaktadır (Duberley ve Cohen, 2010).

Din sermayesi, inanç alanlarında aktörlerin sahip olması gereken özel bir sermaye biçimidir. Aktörün ekonomik, sosyal, kültürel ve sembolik sermayeye aynı anda sahip olması, inanç alanlarında kendisine önemli bir avantaj sağlamaktadır (Crossley, 2001). Bu açıdan düşünüldüğünde din sermayesi, inanç alanlarında hâlihazırda var olanlar ile alanlara girmeye çalışan tüm aktörlerde bulunması zorunlu bir özellikler bütünüdür. Doğuştan gelen ve sonrasında eğitimle geliştirilen kişisel sermaye, sürekli geliştirilmesi ve korunması gereken bir değerdir. Kişinin yalnızca ekonomik birikiminden farklı olarak kendi eğitimine ve akademik gelişimine yapacağ 1 katkı, gelecekte onun dini inanç alanlarındaki belirleyici konumuna da atıf yapacaktır (Lau, 2004; Mayrhofer vd., 2004a).

\subsection{Dini İnanç Habitusunun Oluşumu}

Bourdieu'ya göre habitus, bir aktörün sözlü ve uygulamalı tezahürleri ve söylemlerini önceden biçimlendiren bir alg1, düşünce, hissetme, değerlendirme, konuşma ve oyun kalıplarının bir birleşimidir (Bernstein, 2003). Bireyin geçmişten gelen edinimleri ve şuandaki yaşantısının yeniden üretimi olan habitus, dış dünya ile öznel niyetlerin zaman 
içinde düzenli bir form almasına da vurgu yapmaktadır. Bu yönüyle dini inanç habitusu, bireyin herhangi bir dine inanmadan önceki deneyimleri, bir dini kabul etme sürecinde yaşadıkları veya kazanımları ile bir dini yaşantı oluşturma sürecindeki üretim ve yeniden üretim eylemlerini içerir (Iellatchitch, Mayrhofer ve Meyer, 2003). Yani habitus, dini inancın oluşum sürecinden itibaren kişinin dünyayı algılayış biçimini etkileyerek, o dine olan aidiyet bitinceye kadar olan tüm üretim faaliyetlerinin içinde olan bağlamın ifadesidir.

Bireyin dini inanç oluşumu için elzem öneme sahip olan dini alışkanlıklar, rutinler ve yeni durumlara uyum, habitus bağlamında incelenmektedir (Crossley, 2013). Dini yaşant1 sürecinde sosyalleşme büyük önem taşımasına rağmen, habitus gelişimi o dönemle sınırlandırılamaz. Habitus, bütün hayat boyunca, bir dine ilişkin olumlu ve olumsuz tecrübelerle sürekli takviye edilmektedir. Kısaca belirtmek gerekirse kişinin sosyal alanı algılama biçimi olan habitus doğuştan gelen ve edinilen sermayeye bağlı olarak kişiyi yeniden şekillendiren ve dini yaşantısına yön veren bir kavramdır (Jokinen, Brewster ve Suutari, 2008). Kişinin yaşadığı sosyal alana uygun davranması veya sosyal alana göre kendi yaşantısını düzenlemesi de habitustur (Crossley, 2001). Yani bir kişinin dini inançlarını, kendi sermayesine (ekonomik, kültürel vb.) uygun olarak yönlendirmesi ve bu kapsamda inancın gerektirdiği şekilde yaşaması habitus iken, dini inanışlarına uygun bir sermaye oluşturma çabası da habitustur. Örneğin kişinin Kur'an-1 Kerim'i daha iyi anlama amacıyla Arapça öğrenmesi bir sermaye birikimidir ve Arapça dil bilgisiyle dini inanışlarını çeşitlendirmesi de kendi içindeki gerçekliğe ve habitusa vurgu yapar.

Dini inanç habitusu, belirli dini inanç alanlarında gerçekleşen mücadele, strateji ve planlardan oluşur. Hem bir inanç alanının yapısal bir ürünü (opus operatum) hem de bu alanların yeniden yapılandırılması (modus operandi; Bourdieu, 1990a) olan inanç habitusu, inanç alanlarının yapısal bağlamları ile birey arasındaki karşılıklı ilişkileri de belirlemektedir. Genel olarak habitus sosyal bir çerçeve içinde gelişen bir yapıda iken inanç habitusu daha sınırlı ancak daha yoğun bir etkiye sahiptir (Iellatchitch, Mayrhofer ve Meyer, 2003). Belirli bir inanç alanı içinde oluşan habitus, dini inanç habitusu olarak adlandırılır ve bu inanç alanında yer alan aktörlerin de inanç habitusunu aksi düşünülmez bir şekilde kabullenmesini gerektirir (Mayrhofer vd., 2002). Dini inanç habitusu, kişinin inanç alanlarına girmesi ile kendi gerçekliğinden sıyrılarak dini inanç alanının verili kurallarıyla örtüşmesini ve 'otomatik' gerçekleştirilen eğilimleri de gerekli k1lar (Vilhjálmsdóttir ve Arnkelsson, 2013). Yani kişi belirli bir konumdaki dini bir gruba girmek istiyorsa söz konusu dini grubun koşullarına uymalı ve bu koşulları içselleştirmelidir. Dini inanç alanları rasyonel aktörlerle şekillenir ve bu aşamada yalnızca din sermayesi en iyi olanlar, söz konusu dini gruplar tarafından tercih edilir (Dore, 2004). Bu açıdan dini inanç habitusu, duygusallıktan uzak yüksek düzeyde rasyonel kişilik ve uyum yeteneği gerektirir (Crossley, 2003). Uyumun gücü arttıkça dini inanç alanlarında var olma savaşı veren kişi, bu duruma alışacak ve inanç alanı içindeki eylem ve davranışları alışkanlığa dönüşecektir. $\mathrm{Bu}$ alışkanlıklar, belirli bir süre sonra inanç alanının rutinleşmesine ve herhangi bir dış etki olmaksızın sürdürülebilir duruma gelecektir (Bernstein, 2003). İşte kişinin içinde olduğu bu yeni gerçeklik hali, dini inanç habitusudur. İnanç habitusu, tüm aktörler için yeni dini inanç alanlarını tanıma ve bu alanlara nasıl girileceğini ve alanlarda nasıl hareket edileceğini bilme gibi yeni imkânlar da sunmaktadır (Bourdieu, 1987; 1990a).

Dini inanç habitusu, bir oyuncunun alan kurallarına göre hareket etmesini, algılamasını ve düşünmesini sağlar (Duberley ve Cohen, 2010). İnanç alanının bağlamını kabul eden aktörün, bu alanda yaptığı söylem ve eylemler 'doğal' görünür. İnanç alanı içinde kendi mücadelesini veren aktör aynı zamanda kendi sermayesini maksimize etmeye çalışmaktadır (Delamont ve Stephens, 2008). Bu dinamik ilerleme hali, alanın kurallarına göre farklı 
biçimlerde olabilir: hiyerarşik statünün yükselmesi, sosyal itibarını arttırmak veya daha yüksek bir uzmanlık seviyesi geliştirmek vb. Bu durum dini inanç habitusunun, aktörlerin gelişme ve ilerlemesini öngören doğasının ürünüdür (Crossley, 2001). İnanç alanlarında yer alan aktörler tarafindan döngüsel bir ilişkiyle üretilen habitus, alandaki aktörlerin gelişmişlik seviyesi, oyun alanındaki hâkim durumlar ile mücadele biçimlerini de belirlemektedir (Bourdieu, 1988). Örneğin din eğitimi almış bir aktörün, inanç alanında kendi sermaye birikimine uygun şekilde davranması istenmekte, farklı yönelimlere talip olması durumunda oyundan çıkarılmaktadır. İnanç alanlarında aktörlerin düşünce ve eylem mantığı hem dini inanç habitusuna hem de oyunun gerekliliklerine göre şekillenir (Bourdieu, 1990b). Dini inanç habitusu aktörlerin algıları, motivasyonu ve eylemlerini şekillendirmekte ve aktörlerin inanç alanlarının kurallarını tanıması ve kurallara uygun davranmasını zorunlu tutmaktadır. $\mathrm{Bu}$ açıdan inanç habitusu zorunlulukların eğilimlere dönüşmesini ifade eder (Bourdieu, 1987; 1990a).

\subsection{Dini İnanç Habitusunun Boyutları}

Potansiyel olarak gerçekleşmiş tasarrufların dayanıklı ama gelişen bir sistemi olarak ifade edebilen dini inanç habitusu, aktörlerin yalnızca belirli bir inanç alanı içindeki varlığını değil, aynı zamanda alan içindeki hâkim konumu ile alanın kurallarıyla en iyi şekilde uyuşması anlamına da gelmektedir (Jarness, 2017). Böylece, inanç habitusu, oyunun kurallarını mükemmel bir şekilde bilen ve kullanan, "oyun hissini" derinlemesine içselleştiren ve kendi ilerlemeleri için illusio'yu yani alanın belirli bir oyununa olan inancı belirleyen aktörlere atıf yapmaktadır (Bourdieu, 1996). Söz konusu aktörler, alana önceden girip "köşe başlarını tutan" ve oyunun kurallarını belirleyen konumda olabilecekleri gibi, belirli yetenekleriyle (din sermayesi) alandaki diğer aktörlerden sıyrılan yeni aktörler de olabilir (Crossley, 2013). Dini inanç habitusu içinde dört tip aktör bulunmaktadır (Bourdieu, 1990a; 1996; Iellatchitch, Mayrhofer ve Meyer, 2003; Jarness, 2017):

(1) baskın veya egemen aktör (alanın kurallarını koyan, alandaki tüm mücadeleyi belirleyen ve genellikle nesiller boyu alana hükmeden aktörlerdir; alandaki diğer aktörler, egemen aktöre göre eylemlerini belirlerler),

(2) ylkıcı ve saldırgan aktör (alandaki her işe saldırır ve her şeyi sahiplenmek ister, alanda bir yenilik yapmaz ancak saldırgan tutumuyla kendine bir yer edinir, alandaki büyük aktörler tarafından saygı görmez ve ciddi bir rakip olarak algılanmaz),

(3) farklı yetenek ve özellikleri olan yaratıcı ve yenilikçi aktör (alanda bulunan eski aktörlerin en çok korktuğu ve alanda radikal değişiklik yaratma potansiyeli en fazla olan kişidir; alandaki büyük aktörler tarafından her zaman takip edilir ve alanda yer kapma mücadelesi engellenir),

(4) edilgen aktör (çoğunlukla aile, belirli dini veya ideolojik gruplar veya hemşericilik, adam kayırmacılığ 1 gibi durumlar neticesinde alana giren aktördür, genellikle pasif karakterde ve alan uzmanlığı olmayan bu aktörler, belirli bir grup tarafindan desteklenmeden alandaki mücadeleye girişemezler; alandaki hiçbir aktör, pasif aktörlere saygı duymaz ve rakip olarak görmez, ancak pasif aktörün arkasındaki güce sayg1 duyulur).

Egemen aktörler zamanla inanç alanlarını kendi istek ve ihtiyaçlarına göre oluşturur ve dini inanç habitusuna yön verirler (Bordieu, 1996). Toplumun ihtiyacı olan din adamlarının yetiştirildiği eğitim sistemi de egemen aktörlerin kontrolündedir. Egemen aktörler, istihdam politikalarına, ekonomik yapılara ve inanç alanlarının olası evrimlerine de yön verirler; ayrıca dini inanç ve ibadet gereklerinin zamanla değiştirilmesi, bir inanışın yüceltilmesi, 
farklı habitus ve inanç alanlarının oluşturulması da egemen aktörlerin baskın eylemleriyle gerçekleştirilir (Chudzikowski ve Mayrhofer, 2011). Bu, dini inanç habitusu içinde ve inanç alanlarında farklı biçimlerin bir arada bulunduğu anlamına gelir. Alanın yapısına bağlı olarak, egemen konumlara erişmek için belirli aktörler az ya da çok ayrıcalıklı olacaktır. Egemen aktörlerin önemsemediği veya çok fazla değer atfetmediği bazı aktörler sıyrılarak egemen aktör olabilir (Savickas, 2005). Bu durum özellikle İslami gelenekte yer alan tarikatlar ve cemaatlerde yaşanmaktadır. Yeni toplumsal gelişmeleri daha hızlı içselleştiren ve alana yeni giren aktörler, egemenlerin dikkatini çekmeden baskın konuma erişebilirler. Ayrıca devlet, dini alanları kontrol altında tutan politikalarla yeni aktörlerin rekabetçi girişimlerini destekler ve inanç alanlarının sürekli canlı kalmasına da katkıda bulunur. Devlet eliyle yaratılan bu durum da yeni bir habitus alanı oluşturmaktadır. Dini inanç habitusu sosyal bir yapıya işaret ettiği için gerek liberal gerekse devlet eliyle oluşturulan tüm toplumsal alanlar kendisine yeni sosyal gerçeklikler oluşturacak ve bu durum da yeni habitusların oluşmasına yol açacaktır (Mayrhofer vd., 2004a; Wacquant, 2014).

Dini inanç habitusu, aktörlerin alandaki davranışlarını etkileyen belirgin, özgün ve yaygın rol kalıpları da oluşturur (Giddens, 2013). Nitekim dini inanç alanlarında olmak isteyen herkes aslında bir kariyer alanındadır. Bundan dolayı alanda bulunan her birey, inanç alanına taşınmaya yönelik, potansiyel olarak gerçekleşen hükümlerin kalıcı ancak gelişen bir sistemi olarak tanımlanan bir dini inanç habitusuna sahip olacaktır (Chudzikowski ve Mayrhofer, 2011; Iellatchitch, Mayrhofer ve Meyer, 2003). Dini inanç habitusu, inanç alanlarında yer alan aktörlerin farklı eylem olasılıklarının da sonsuzluğunu belirleyen genel bir kavramdır (Jarness, 2017). Örneğin bir kişi işinden mensubu olduğu dinin gereklerinden hoşlanmaz, bu gerekleri yerine getirmez ve yine de dine inanmaya devam ederse, her geçen gün inandığı dinin gereklerinden kaçmak için stratejiler düşünecek ve inandığ dinin emrettiği esaslara karşı ilgi duymayacaktır. Bu kişi, düşünce ve eylemleriyle belirli bir inanç habitusu geliştirmiştir.

Dini inanç habitusunu içselleştiremeyen ve inanç alanlarından çekilmek isteyen aktörlerin tasfiyeleri de belirli bir bağlamla gerçekleşir; ancak bu durum inanç alanlarında inatla mücadele eden (saldırgan aktör) meslektaşlarından farklı bir biçimde olur (Vilhjálmsdóttir ve Arnkelsson, 2013). Örneğin bir dini gruptan ayrılma niyetinde olan kişi ya başka bir dini gruba katılmak, ya herhangi bir dini gruba katılmaksızın dini yaşantısına devam etmek veya dini inanışından tamamen vaz geçmek gibi alternatifler arasında seçim yapacaktır. Kişinin bu seçimi, habitusu ne derece içselleştirdiği ve dini sermaye birikimini ne derece sağladığıyla ilgili olup, dini sermayesinin farklı değeri ve nitelikleri, yani kişinin elinde bulunan ve elde ettiği farklı sermaye ve destek yöntemleri belirleyici olacaktır. İnanç alanlarından çıkma niyetinde olan kişiler, daha sonraki yaşantıları için yatırım yapabilir ve kendilerini daha zorlu mücadelelere hazırlayabilir (Iellatchitch, Mayrhofer ve Meyer, 2003). Görüldüğ̈̈ üzere özellikle din psikolojisi alanındaki pek çok kavram aslında kişinin habitus haline odaklanırken, habitusun varlığına atıfta bulunmakta ve dini inanç habitusunun çok yönlü doğasını belirlemektedir.

Habitustan farklı olarak dini inanç habitusu çeşitli boyutlarda oluşan eylem ve davranışların bir bileşkesi şeklinde gerçekleşmektedir (Mayrhofer vd., 2004). İnanç alanlarındaki her eylem ve davranış dini inanç habitusunun farklı bir boyutunu temsil etmeyken, alandaki aktörlerin bu boyutların farkında olduğu ve alana yeni girecek aktörlerin bu boyutları zamanla içselleştirdiği düşünülmektedir (Robbins, 2005). Dini inanç habitusu bilinçsizlik (unconsciousness), istikrarlılık (stability), sosyal birleşim (social integration) ve stratejik eylem (stratejik action) olarak belirlenmiş dört ana boyuta sahiptir (Bourdieu, 1990a; 1996). 


\subsubsection{Bilinçsizlik}

Kişinin bilinç düzeyindeki farkındalıklarına odaklanan bilinçsizlik boyutu, bilişsel habitus süreçlerine odaklanmaktadır. Bilişsel habitus, kişinin yaşamı boyunca bilinçaltı seviyede çalışan ve bu nedenle, yenilik ve değişime büyük oranda direnen bir eğilimlerini içermesinin yanında bilinçli olarak yaptı̆̆ tüm davranışlar da dini inanç habitusunca oluşturulur (Bourdieu, 1996). Yani bir kişi, aiti olduğu dini grubun üstlerinden aldığı bir emri olumlu veya olumsuz bir iç değerlendirmeye tabi tutarak tamamen bilinçli olarak kabul edeceği gibi (bilinçlilik hali), herhangi bir iç değerlendirme olmaksızın da kabul edebilir (bilinçsizlik hali). Kişinin karar ve seçimlerindeki farkındalık durumuna odaklanan bu boyut, habitusun bireysel desenini oluşturmaktadır (Nora, 2004). Bilinçsizlik boyutu, aktörler arası takas ilişkilerinden farklıdır ve özellikle aktörler arasındaki mücadele ve çıkar ilişkilerine odaklanmaktadır (Lau, 2004). Bilinçsizlik boyutu, "anlaşılabilirlik" (comprehensibility) ve "aksi düşünülmez" (taken-for-grantedness) yapılara atıfta bulunur (Bourdieu, 1996).

Anlaşılabilirlik, bilincin farklı gerçeklikleri oluşturması ve bu gerçekliklerin habitus tarafından kapsanmasıdır. Tek başına anlaşılamayan pek çok yapı, kapsayıcı bir bilinçsizlik hali ile düzenlenmekte, anlam kazanmakta ve aktörlerin eylemlerine yön vermektedir (Bernstein, 2003). Kapsayıcılık bilinçaltının farklı eğilimlerini de içerse de genellikle kişilerin belirli bir bağlam içinde davranmalarına imkân tanımaktadır (Higgins, 2001). Örneğin bir kişi, aiti olduğu dini grubun kanaat liderlerini ve kendisi gibi diğer takipçileri anlayabildiği ve kendisinin anlaşıldığını düşündüğü dini gruplara katılma eğilimi içinde olacak ve memnun olmasa da bu dini gruplarda yer almayı sürdürecektir. Kişinin bu seçimi kapsayıcı bilinçsizlik olarak ifade edilir, çünkü kişi, kendisi için rasyonel olanı değil duygusal olanı seçmiştir. Bilinçsizlik boyutu kişilerin eylem ve davranışlarının kapsayıcı bir desende olmasının ön koşulu olarak, eylem veya davranışın öngörülebilir (predictability) ve akla yatkın (plausibility) özellikler taşıması gerektiğine de vurgu yapmaktadır (Bourdieu, 1996). Buna göre bir kişi herhangi bir dini grupta öngörülebilir bir dini sermaye gelişimi ve bu gelişimin güvencesini istemektedir. Kişinin bu isteği akla yatkındır ve akla yatkınlık rasyonel davranışın doğasını belirlemektedir. İnsanlar belirsizliklerle dolu ve öngörülemeyen koşulların olduğu ortamlarda bulunmaya akla yatkın bulmazken, dini gruplara yön veren kanaat liderleri de davranış ve eylemleriyle öngörülemeyen bir kişinin kendi dini gruplarında yer almasinı tercih etmemektedir (Mayrhofer vd., 2004a; Savickas, 2005).

Aksidüşünülmezlik, bilinçsizliğin dışsal nesnelliği yeniden üretmesi ve dışsal yapıların inanç alanlarını baskılaması, bu şekilde aktörlerin aksi düşünülmez eylem ve davranışlara sahip olarak mücadelenin var olan kurallarını yeniden üretmesidir (Robbins, 2005). Yani, inanç alanlarındaki mücadeleye ilişkin kuralların, kuralları ilk oluşturan egemen aktörlerin kontrolünden çıkarılması ve böylece kuralların herkesi kapsayan bir tahakküme eriştirilmesidir. Aksidüşünülmezlik, bir davranış, eylem ve roller takımıdır ve toplumsal gerçekliği kavrayan ve içselleştiren bireylerin beklenti ve isteklerine cevap veren kurgulanmış sosyal gerçekliktir (Bourdieu, 1996). Aksidüşünülmezlik toplumun genelince kabul edilmiş bir dini gerekliğin veya değerin, toplumsal sözleşme ile genelleştirilmesi ve söz konusu dini gerekliğin toplumsal yaşam ve bireyin varlığı alışkanlığa dönüşerek herhangi bir dış müdahaleye gerek duyulmaksızın süreklilik kazanmasıdır (Giddens, 2013). Aksidüşünülmez yapılar, inanç habitusunun en önemli kalıpları olarak belirir ve toplum genelince fazlasıyla kabul görürler. Bireyler aksi düşünülmez kalıplarla yaşadıkları dünyayı anlamlandırmakta, toplum içinde nasıl davranacağını bilmekte, hangi beklentilerin akla yatkın olduğunun farkında olmaktadır (Robbins, 2005). Örneğin okul kavramı, sanayi toplumunun bir gereği olarak kurumsallaşmıştır ve toplum için tarihsel olarak bir gerekliliğe dönüşmüştür. Bugün toplumda yaşayan her çocuk belli bir yaşta okula gitmekte ve bu durum 
onlar için aksi düşünülmez bir gerçeklik olmaktadır. Bunun yanında çeşitli dini uygulamalar, askerlik, evlilik ve diğer sosyal gelenekler de belirli aksi düşünülmez gerçeklik alanları oluştururlar. Bir dinin inananları için aksidüşünülmezlik o dine ait süregelen iman ve ibadet esaslarıdır. Bu nedenle bir dinin inananlarına yönelik farklı ve yeni uygulamalar, aksi düşünülmez yapılarla çatışmamaya ve inananların aksidüşünülmez gerçeklik bilincini koruma eğilimindedirler (Brenstein, 2003).

\subsection{2. İstikrarlılık}

Aktörlerin eylem ve davranışlarının temelinde yatan tarihselliğe vurgu yapan istikrarlılık, çocukluk döneminden başlayan sosyalleşme süreçleri boyunca ve çocuğun içinde yer aldığ sosyal sınıfın bağlamına göre oluşan kısıtlamalar ve özgürlüklere bağlı öğrenmelere atıf yapar (Bourdieu, 1996). Kişinin içinde olduğu habitus, bu süreçler boyunca oluşturulur ve kişinin davranış ve eylemlerine istikrarlı bir şekilde yön verir. Kişi yaşamı boyunca habitus tarafindan oluşturulan istikrarı ve denge durumunu sürdürmek ister. Bu habitusun doğuştan olduğu anlamına gelmese de 'inancın dönüştürücü etkisi', yani ikincil nesnel etkileşimler (dini gruplar içinde sosyalleşme) istikrarın oluşunda söz konusu olabilir (Savickas, 2005; Wacquant, 2014). Dini inanç alanlarındaki aktörlerin ilişkileri, kurumsal ya da öznel kısıtlamaları aşan farklı sansür ve engellemeleri diğer aktörler için zorunluluk haline getirebilir (Bourdieu, 1990a). Bu durumda dini inanç habitusu, kişi için istikrarı oluşturan ve onu sürekli kılan bir zorunlu uyumluluk veya tahakküm alanı oluşturmaktadır. Dolayısıyla, dini inanç habitusu, inanç alanlarındaki deneyimlerini bünyesinde barındırması nedeniyle kişinin sosyal geçmişi veya dine ilişkin hatıra ve deneyimleri anlamına da gelir (Crossley, 2003).

İstikrarlılık büyük ölçüde sürekliliğin algılanması ve kurumsallaşmış eylemlerin sürekliliğiiyle ilişkilidir. Dini inanç habitusunun istikrarlılığı, inanç alanlarında mücadele eden aktörler tarafından oluşturulmuş gerçekliğin sürdürülmesi amacına hizmet etmektedir (Lau, 2004). Dini inanç alanlarındaki egemen aktörler, istikrarı belirsizliğe tercih ederler; çünkü belirsizlik, inanç alanlarına hükmeden egemenlerin iktidar alanlarının daralmasına veya iktidarlarının sonlanmasına yol açabilir. Bunu bilen egemen aktörler, inanç alanlarında istikrarın sürdürülmesi ve istikrar olgusunun sürekli bir şekilde bireylerin bilincine işlenmesi gerektiğini düşünürler (Bourdieu, 1990a). Egemen aktörler, diğer aktörlerin inanç alanlarında istikrarı arayan bir eylem dizgesini sürdürmek istediklerinden, belirsizlik olgusunu bertaraf etmek için belirsizliğe yol açan her durumu 'ötekileştirmekte' veya 'şeytanlaştırmaktadır' (Duberley ve Cohen, 2010). Örneğin bir dini gruba üye olan kişi, bu grup içinde edineceği tecrübeleri bilmek ister, eğer kişi uzun bir süre söz konusu dini grubu takip edip beklediği kazanımları elde edemezse bu durum onun için bir istikrarsızlıktır. Başka bir ifadeyle kişinin talebine cevap verilemeyen durumlarda kişi yalnızlaşarak dini gruptan ayrılma veya grup içinde sindirilme veya ötekileştirme gibi olumsuz davranışlara maruz kalacaktır. Kişinin yaşayabileceği bu durum belirsizlikten kaçınma halidir ve özelde istikrarlılı̆̆ın, genelde ise dini inanç habitusunun önemli bir bileşenidir.

\subsubsection{Sosyal Birleşim}

Habitusun bu boyutu, toplumsal yapıların birleşimi olarak anlaşılabilir. Bilişsel, algısal ve eylem matrisinin bir etkileşimi olan sosyal birleşim, bilişsel yapıların yanı sıra içselleştirilmiş toplumsal yapılar olarak da görülür. Dolayısıyla sosyalleşme, toplumsal yapının bireylerin etkinliklerine dâhil edilmesi sürecidir (Bourdieu, 1977). Sosyal birleşim, sosyal parçaları bir bütün haline getirme olarak değerlendirildiğinde inanç alanlarında oynanan oyunlar, mücadele ve takasların tamamı bu birleşimin bir parçasıdır (Flanagan, 1993). Dini inanç alanlarında gerek düşünsel tartışmaların gerekse aktörlerin serbest 
hareketine engel olan kural ve politikalara son verilmesi; yenileşme ve gelişme politikalarını uyumlaştırıp ayrı ayrı olan sosyal yapıları, din eksenli tek bir bütün haline getirmek de sosyal birleşim olarak ele alınmaktadır (Dore, 2004). Dini inanç habitusu, sosyal birleşimin etkisiyle bireylerin önceki davranışlarını farklılaştırmasını ve yeni bir aktör olarak inanç alanlarında yer almasını gerektirir. Sosyal birleşim, farklı parçaların özelliklerini kaybetmeden ancak yeni özellikler kazanarak bir araya gelmesi ve yeni, eşsiz ve farklılaşmış bir bütünü oluşturmasıdır (Crossley, 2003). Dini inanç habitusu kişinin sosyal bağlama uygun davranmasını gerektirirken, aynı zamanda bireysel farklılıklarını da inanç alanlarına taşımasını istemektedir. Bir kişi herhangi bir dini grup içinde yer almaya başladığında öncelikle o grubun kurallarını öğrenmesi ve daha sonra grubun kurallarını benimseyip özdeşleşmesi beklenir. Bu beklenti dini inanç habitusunun öznel birleşim özelliğine atıf yapmaktadır. Ancak kişinin özdeşleşmek veya kuralları benimsemek istemesi kendi isteğiyle değil, dini grup içindeki sosyal etki ve baskı veya grup dışına çıkmak istememesi vb. sebeplerle de olabilir. Bu durumda kişinin kendi isteği dişında dini grupla özdeşlemesi, bir zorlamadır ve dini inanç habitusunun nesnel özelliğine vurgu yapar. Verilen örnekte kişinin tüm seçimlerinin, dini inanç habitusunun sosyal birleşimi bağlamında değerlendirilmesi söz konusudur (Mayrhofer vd., 2002; 2004a).

\subsubsection{Stratejik Eylem}

Dini inanç habitusunun stratejik eylem boyutu, aktörlerin uyguladığ 1 farklı ve yeni yöntem, strateji ve taktikleri içermektedir. Aktörler tarafindan içselleştirilen inanç habitusunun algılama, eylem ve yapısal zihniyeti, inanç alanlarının öznel ve nesnel yapısına yöneliktir (Delamont ve Stephens, 2008). Bu öznel ve nesnel yapılar aktörler tarafindan dini, ekonomik, kültürel ve sosyal sermayenin spesifik kombinasyonları olarak görülür. Bourdieu tarafindan dönüştürücü eylemler bütünü olarak ifade edilen "strateji" kavramı, habitusun doğasında bulunması gereken bir "eylem üretme prensibi" olarak tanımlanır (Bourdieu, 1990b). Stratejinin bu özel tanımı tenis oyunu aracılığıyla örneklendirilebilir. Maç sırasında, oyuncu, her bir vuruşa uyum sağlamak ve diğer oyuncu tarafına kendi stratejisine uygun vuruşlar yapabilecek yetenekte olmalıdır. Oyunun kuralları açıkça tanımlanmış olsa bile, oyuncular kurallara mekanik olarak itaat etmek yerine oyunu kazanmak için yaratıcı vuruşlar ve yeni teknikler denemeli ve stratejik bir çerçeve oluşturmalıdır (Bourdieu, 1990a). Oyuncular, oyunun akışına göre hareket ederek, oyun üzerinde bazen çok düşünmeden bazen ise baskın bir strateji uygulayarak oyunu kazanmak için yapması gerekenleri yaparlar. Din alanına dönülürse, dini inanç habitusu, oyunun derinden içselleştirilmiş bir anlayış tarafindan yönlendirildiği ilkesine dayanmaktadır. İnanç alanları tenis oyunları kadar hızlı kararlar almayı ve bir o kadar çetin mücadeleleri içerdiği için oyuncular, zaman zaman ciddi stratejik planlamalar yapsa da çoğu durumda oyun üzerinde gerçekten düşünmeden, anlık veya duruma uygun bir şekilde hareket edecektir (Bourdieu, 1996). Özellikle din alanlarında yapılan günlük popülist tartışmalar bu duruma örnek olarak verilebilir.

Strateji, belirli alanda devam eden mücadelelerde illusio arayışı içinde olan aktörlerce yürütülen ve habitus tarafından üretilen, refleks olmayan eylemdir (Lau, 2004). Askeri alanda gelişen kavram, temelinde rasyonel seçim kuramına dayalıdır (Knights ve Morgan, 1990) ve aniden ortaya çıkan bir duruma karşı ani bir refleks olmasından ziyade, bir hedefe ulaşmak için uzun süredir devam eden bir eylem planı olarak ifade edilebilir. Açıktır ki, Bourdieu'nun strateji kavramı, sermayeye ve/veya iktidara sahip olanların sosyal olarak egemen olma isteğinden ziyade, mücadele alanlarını analiz etmeye ve beklenmedik durumlara veya mücadelenin olağan akışı içerisinde yer alan diğer aktörlerin eylemlerine daha uygun cevaplar verme arayışı olarak görünmektedir (Lau, 2004). Örneğin bir dini gruba katılma niyetinde olan veya dini grubu dışarıdan etkilemeye çalışan kişinin kendi 
sermayesine uygun olarak hareket etmesi ve yalnızca bu sermaye özelindeki arayışı bir strateji iken, kişinin içinde bulunduğu şartların değişip ağırlaşmasıyla farklı sosyal gerçeklikler içinde olması ve kendi sermayesi kapsamında olmayan işlere yönelmesi de söz konusu olacaktır. $\mathrm{Bu}$ ikinci durum refleks gibi görünmesine rağmen esasen kişinin içinde bulunduğu şartların (habitus), onu mümkün olan herhangi bir duruma yönlendirmesidir (Chudzikowski ve Mayrhofer, 2011).

Habitus ve dini inanç alanları arasındaki denge durumu, alanın mücadeleyi yeniden üreten doğasına kaynak veya imkân sağlayan sosyal kısıtlamaları aşmaya yönelik yeni ve farklı stratejiler geliştirme eğilimindedir (Bourdieu, 1996). Yani dini inanç habitusu, inanç alanlarının durağan olarak kalmasını istemez, bunun yerine inanç alanları ve inanç alanında yapılan mücadeleler sürekli olarak devinim içinde olmalıdır. Bu sayede habitus kendi gerçekliğini yeniden ve yeniden üretip, kişiler üzerindeki etkisini sürekli kılabilir. Bu eğilim, alanın genel işleyişinin sorgulanmaması veya alandaki kuralların eleştirilmemiş olmasıyla ilgilidir. Yani bir dini grubun lideri konumunda olan kişi, inancın gereklerine uygun ve kendisine itaat etmeye hazır bir inanan kitlesi ararken, inancın gerektirdiği nitelikleri karşılamayan ancak farklı ve özgün nitelikleri olan kişileri kendi dini grubuna kabul etmeme eğilimindedir. Dini grup önderinin bu tutumunu sorgulayıp eleştirecek bir makam bulunmaz. $\mathrm{Bu}$ durum ancak habitusun etkisiyle aşılabilir. Bu noktada habitus evrilir ve kendi içinde gelişimi sağlayacak denli döngüsel bir yapıya sahip olursa, hem kaynak ve imkânları yeniden değerlendirecek hem de aktörlerin yeni inanç seçimlerine ve böylece yeni inanç stratejilerinin oluşumuna yol açacaktır (Crossley, 2013; Giddens, 2013).

\section{Tartışma ve Sonuç}

$\mathrm{Bu}$ çalışma temel olarak habitus kavramına odaklanmış ve habitus kavramının dini inanç alanlarını, din sermayesini ve son olarak da dini inanç habitusunu oluşturma sürecini analiz etmiş̧tir. Toplum karmaşı güç ilişkilerini ve yaşam alanlarını barındıran bir bütündür. Kişinin toplum içinde var olmasından itibaren yaşamının tüm alanları çeşitli toplumsal yapılar içinde geçmekte ve toplumsal sistem kişilere çeşitli sosyal gerçeklik reçeteleri sunarak kendi varlıklarını devam ettirmektedirler. Kişinin sosyalleşme süreciyle birlikte toplumsal sisteme girmesi ya bu sistemi değiştirecek şekilde ya da olduğu gibi kabul edecek şekilde davranmasını konu edinen habitus, kişinin ne yapması, nasıl davranması gerektiğini ona hissettiren ve bu şekilde sosyal alanlarda düzen, istikrar ve bütünleşmeyi öngören bir kavramdır. Habitusun karmaşık yapısı, sosyal gerçekliğin anlaşılması hususunda farklı etkenlerin dikkate alınmasını zorunlu kılar. Sosyal gerçekliğin nesnel ve öznel yanlarını beraber ele alarak bireyleri etkileyen habitus kavramı daha kolay anlaşılmaktadır. Bir taraftan üretici bir yapı olan habitus, aynı zamanda alan tarafından üretilen bir yapıdır. Sosyal alanlarda nesnel olarak hüküm süren gerçekliğin katı ve kurumsallaşmış biçimi, kişinin eylemleri üzerinden belirmekte ve kişiler ile toplumun sahip olduğu sermaye ve bilgi dağarcığıyla habitusu şekillendirmektedir. Toplumun ortak sermaye ve hafızasına dayalı olarak genişleyen bilgi stokları, benzer eylem stratejilerini ortaya çıkarır ve bu stratejiler, bireyler arasında ortak bir habitusu ve sonrasında da kurumsallaşmayı meydana getirir.

Habitus, üyesi olduğu toplumsal tabaka veya sınıfın davranış kodlarıyla hareket eden bireylerin, tüm bu davranış ve eğilimlerini yönlendiren itici güçtür. Bir nevi eğilimler toplamı olarak belirleyebileceğimiz habitus, sabit ve değişmez bir yapı olmaktan ziyade alanın kurgusal yapısına göre değiştirilebilir ve yeniden üretilebilir. Habitusun böylesi dinamik yapısı, sosyal gerçekliğin devam etmesinin bir sonucudur. Bourdieu'nun tasavvur ettiği habitus, kuramsal ve uygulamalı bilgilerin oluşma ve yapılaşma ilkesi olarak işleyen belirli toplumsal alanlarda üretilen sürekli ve dönüştürülebilir eğilimler sistemi olsa da özünde nesnel dünyanın özneleşmesidir. Bu özneleşme belirli alanlarda, belirli sermaye 
koşullarında ve belirli stratejiler kullanılarak gerçekleştirilmektedir.

Dini inanç habitusu, bir dine inanan ve o dinin gereklerini yapmaya çalışan kişinin inanç alanlarına girmesi, inanç alanlarında yer alan dini gruplar ile temas etmesi ve bir dini gruba katılması veya bu alanları terk etmesindeki nesnel algının özneleşmesini konu edinir. Dini inanç habitusunun şekillendirdiği kişi ya tamamen nesnel kaygılarla veya öznel seçimlerle inanç alanlarına girmektedir. Herhangi bir dini inanışta olan kişinin, bu inanışı idame edeceği bir dini grup içinde yer alması yaşamın olağan akışıdır. Ancak bu grup arayışı kişinin kendi isteğiyle mi yoksa dişsal zorlamalarla mı gerçekleşmektedir? İşte bu soru habitus kavramının kısa bir özetidir. Habitus kişinin dış dünyanın etkisiyle oluşturduğu içsel gerçeklikler olarak tanımlandığında, kişinin dini yaşamını devam ettirmek için bir dini gruba katılmaya çalışması gerçeği bir öznel zorunluluk olurken, aldığı eğitimin veya toplumsal düzenin gerektirdiği şekilde dini gruba katılmaya zorlanması dışsal bir zorunluluktur. $\mathrm{Bu}$ noktada habitus: "kişi topluma uyum sağlamak veya dini yaşamını devam ettirmek istiyorsa bu gereklikleri yerine getirmelidir" şeklinde beliren hem dişsal ve hem de içsel zorlamalara atıf yapar.

Dini inanç habitusu, inanç alanlarında gerçekleştirilir. İnanç alanları somut bir coğrafi alandan ziyade kişilerin algıladıkları dini yaşama ve bu dine ilişkin sermaye edinme alanlarını ifade eder. Bu alanlarda bulunan aktörler veya oyuncular tarafından belirli oyunlar veya mücadeleler verilmektedir. Mücadeleler, inanç alanlarına önceden girmiş aktörlerce belirlenen kurallar çerçevesinde yapılır. Bu kurallar o dinin yazılı metinlerine atıfta bulunabileceği gibi dinden tamamen bağımsız bir şekilde de olabilir. İnanç alanlarına girmeye istekli aktörlerin bu mücadeleyi ve oyunun kurallarını kabul etmesi gereklidir. Aktörler, inanç alanı içindeki diğer aktörlerin farkındadır ve kendi konumlarını bu aktörlerin davranış ve eylemlerine göre belirlerler. Aktörlerin davranış ve eylemleri ise strateji olarak adlandırılan tepkiler veya yöntem ve tekniklerdir. Aktörler, inanç alanlarında kendi dini sermayelerine uygun stratejiler geliştirmelidirler. Sermaye aktörün tüm bilgi ve deneyimini oluşturur ve birçok durumda kişinin dini yaşantısını devam ettirmesi için gerekli yetenekleri de kapsamaktadır. Dini inanç habitusu bilinçsizlik, istikrarlılık, sosyal birleşim ve stratejik eylem olarak belirlenmiş dört ana boyuta sahiptir. Her aktör bu boyutları farklı düzeylerde yaşayarak kendi dini inanç habitusunu üretirler.

Dini inanç habitusu, kişinin, modern toplumun şartlarına uygun bir şekilde yaşamasını da gerektirir. İlkel toplum yapıları ayrı tutulduğunda, günümüzde kişinin inanç alanlarına girmeksizin herhangi bir dini yaşantıyı sürdürmesi mümkün değildir. Bu açıdan inanç habitusu, yalnızca sosyal bir etki değil aynı zamanda bir tahakküm aracıdır. Kişi inanç alanlarının öngörülebilir olmasını ve dini yaşamının uzun süre devam etmesini ister. Kişinin bu isteği, temelde dini yaşamında sürdürülebilir denge durumunu araması ve istikrarlı bir inanca kavuşmak istemesinden kaynaklanmaktadır. Belirsizlikten kaçınan kişiler için istikrar, kişinin öznel iyi oluşundan daha önemlidir. Yani kişi belirli bir dini grup içinde mutsuz dahi olsa o gruba olan bağını devam ettirme ve düzenini koruma eğilimindedir. $\mathrm{Bu}$ eğilim dini inanç habitusunun varlığını göstermektedir. Dini inanç habitusu öngörülebilir, akla yatkın ve aksi düşünülmez yapılar oluşturarak kişileri kapsamakta ve onların davranışlarına yön vermektedir.

Dini inanç habitusunun varlığını ve kişiler üzerindeki etkilerini belirlemek, kişilerin dini gruplar içindeki davranışlarının nedenlerini, grup seçimlerini, inanç alanlarındaki mücadelelerini ve kişisel sermaye oluşumlarının kökenlerini ve yönelim eğilimini anlamak açısından önemlidir. Dini inanç habitusu, doğumdan itibaren kişinin verili dini yaşam alanlarına katıldığı ana kadar olan dini sermaye oluşumu üzerinde etkilidir. Kişinin dinin gereklerini yerine getirecek bir hazırbulunuşlukta yetişmesi, inanç alanlarının ve grup 
yönelimlerinin ihtiyaçlarına göre eğitim alması, inanç alanlarına katılım öncesi habitus durumuna işaret etmektedir. Kişinin inanç alanına girmesiyle birlikte farklı bir habitus etkisi başlar. Dini inanç habitusunun bu formu, kişinin dini yaşamı boyunca tüm inanç yönelimini belirler ve onun inanç alanlarına girme öncesi dönemde edindiği dini sermayenin geliştirilmesine katkı sağlar. Kişinin dini grup üyeliği bittiğinde dahi dini inanç habitusunun kendisine sağladığı bir sosyal ortam içinde yaşamaya devam eder. Bu durum bir çeşit damgalamadır. Örneğin bir dini gruba katılan kişi belirli bir süre sonra o gruptan ayrıldığında dahi toplum o kişinin geçmişine odaklanacak ve geçmişte dini sermayesini sağladığı gruba olan aidiyetini sorgulayacaktır. Bu kişinin söz konusu dini gruba üyeliği bitse dahi, toplumun bunu kabullenmesi zaman alacak ve kişi ya yeni inanç alanlarına yönelecek veya inancını ciddi anlamda gözden geçirecektir. Bu durum özellikle Hristiyan-Protestan inançtan farklı bir dine geçen kişiler üzerinde görülmektedir.

$\mathrm{Bu}$ çalışma habitus kavramının kökenlerini ve kavramın mekanik yapısına odaklanmıştır. Temelde sosyolojik bir eğilim içinde yapılan analizler, gündelik yaşantıdan örneklerle çeşitlendirilmiş, habitus kavramının anlaşılması için farklı tahayyüller edinilmesi amaçlanmıştır. Sosyal bilimler literatüründe habitus kavramı üzerine bilimsel çalışmalar yapılsa da dini inanç habitusunu Türkçe literatürde ele alan çalışmalara rastlanamamıştır. Habitus çalışmaları, kişiler üzerindeki sosyal etkinin anlaşılması bakımından önem arz etmektedir. Bununla birlikte aktörlerin hangi davranış ve eylemleri meşru kabul ettiği, habitusun aktörler üzerinde tahakküme yol açan etki dizgesi gibi uygulamalı araştırmalara ihtiyaç duyulmaktadır. Özellikle cinsiyet, sosyal statü, sınıf gibi belirleyici değişkenlerin ele alındığı deneysel araştırmalarla kişilerin dini grup seçimi ve dini sermaye gelişimleri üzerindeki habitus etkisi incelenebilir. İleride yapılacak çalışmalar için kavramsal çerçeve oluşturan bu çalışma kullanılarak özelde yönetim bilimleri alanında ve genelde ise çeşitli bilim alanlarında habitus çalışmaları yapılmalıdır. 


\section{Kaynakça}

ARTHUR, M. B., HALL, D. T., \& LAWRENCE, B. S. (1989). Generating new directions in career theory: The case for a transdisciplinary approach. In M. B. Arthur, D. T. Hall, \& B. S. Lawrence (Eds.), Handbook of career theory: 7-25. Cambridge, England: Cambridge University Press.

BARLEY, S. R. (1989). Careers, identities, and institutions: the legacy of the Chicago School of Sociology. In M. B. Arthur, D. T. Hall, \& B. S. Lawrence (Eds), Handbook of career theory: 41-65. Cambridge, England: Cambridge University Press.

BENEVOLO, L., \& Ipsen, C. (1995). The European City. London: Blackwell.

BENHABIB, S. (2002). The claims of culture: Equality and diversity in the global era. Princeton University Press.

BERNSTEIN, B. (2003). Class, codes and control: Applied studies towards a sociology of language (Vol. 2). Psychology Press.

BOURDIEU, P. (1977). Outline of a Theory of Practice. Cambridge, Mass.: Cambridge University Press.

BOURDIEU, P. (1984). Distinction. A Social Critique of the Judgement. Cambridge MA: Harvard University Press.

BOURDIEU, P. (1986). The Forms of Capital. In J. G. Richardson (Ed.), Handbook of Theory and Research for the Sociology of Education. 241-258. New York.

BOURDIEU, P. (1987). What makes a social class? On the theoretical and practical existence of groups. Berkeley Journal of Sociology, 32. 1-18.

BOURDIEU, P. (1988). Homo academicus. Stanford University Press.

BOURDIEU, P. (1990a). In Other Words. Essays Towards a Reflexive Sociology. Cambridge, UK.

BOURDIEU, P. (1990b). The Logic of Practice. Stanford. Stanford University Press.

BOURDIEU P (1996) Physical space, social space and habitus. The Vilhelm Aubert Memorial Lecture. ISO Report, Oslo: University of Oslo.

BURT, R. S. (1992). Structural Holes: The Social Structure of Competition. Cambridge. Harvard University Press.

CHOMSKY, N. (2014). Aspects of the Theory of Syntax (Vol. 11). MIT press.

CROSSLEY, N. (2001). The phenomenological habitus and its construction. Theory and Society (30). 81-120.

CROSSLEY, N. (2003). From Reproduction to Transformation. Social Movements Fields and the Radical Habitus. Theory, Culture and Society, 20(6). 43-68.

CROSSLEY, N. (2013). Habit and habitus. Body \& Society, 19(2-3), 136-161.

CHUDZIKOWSKI, K., \& MAYRHOFER, W. (2011). In search of the blue flower? Grand social theories and career research: The case of Bourdieu's theory of practice. Human Relations, 64(1), 19-36.

DELAMONT, S., \& STEPHENS, N. (2008). Up on the roof: the embodied habitus of 
diasporic capoeira. Cultural sociology, 2(1), 57-74.

DORE, R. (2004). New forms and meanings of work in an increasingly globalized world. Geneva. International Institute for Labour Studies.

DUBERLEY, J., \& COHEN, L. (2010). Gendering career capital: An investigation of scientific careers. Journal of Vocational Behavior, 76(2), 187-197.

DUMAIS, S. A. (2002). Cultural capital, gender, and school success: The role of habitus. Sociology of education, 44-68.

ELIAS, N. (1978). Norbert Elias and "The Civilizing Process". Theory and Society, 5(2), 219-228.

EGERTON, M., \& HALSEY, A. H. (1993). Trends by social class and gender in access to higher education in Britain. Oxford Review of Education, 19. 183-196.

FLANAGAN, W. G. (1993). Contemporary Urban Sociology. Cambridge. Cambridge University Press.

GIDDENS, A. (2013). New rules of sociological method: A positive critique of interpretative sociologies. John Wiley \& Sons.

GRANDJEAN, B. D. (1981). History and career in a bureaucratic labor market. American Journal of Sociology, 86(5). 1057-1092.

HABERMAS, J. (1991). The structural transformation of the public sphere: An inquiry into a category of bourgeois society. MIT press.

HIGGINS, M. (2001). Reconceptualizing mentoring at work: A developmental network perspective. Academy of Management Review, 26(2): 264-288.

IELLATCHITCH, A., MAYRHOFER, W., \& MEYER, M. (2003). Career fields: A small step towards a grand career theory? International Journal of Human Resource Management, 14(5): 728-750.

JARNESS, V. (2017). Cultural vs economic capital: Symbolic boundaries within the middle class. Sociology, 51(2), 357-373.

JOKINEN, T., BREWSTER, C., \& SUUTARI, V. (2008). Career capital during international work experiences: contrasting self-initiated expatriate experiences and assigned expatriation. The International Journal of Human Resource Management, 19(6), 979998.

KNIGHTS, D., \& MORGAN, G. (1990). The concept of strategy in sociology: A note of dissent. Sociology, 24(3): 475-483.

LAU, R. W. K. (2004). Habitus and the Practical Logic of Practice: An Interpretation. Sociology, 38(2): 369-387.

LODGE, G. C. (1995). Managing globalization in the age of interdependece. San Francisco: Pfeiffer.

MAYRHOFER, W., IELLATCHITCH, A., MEYER, M., STEYRER, J., SCHIFFINGER, M., \& STRUNK, G. (2004a). Going beyond the individual. Some potential contributions from a career field and habitus perspective for global career research and practice. Journal of Management Development, 23(9): 870-884.

MAYRHOFER, W., MEYER, M., IELLATCHITCH, A., \& SCHIFFINGER, M. (2004b). 
Careers and human resource management - a European perpective. Human Resource Management Review, 14: 473-498.

MAYRHOFER, W., STEYRER, J., MEYER, M., ERTEN, C., HERMANN, A., IELLATCHITCH, A., MATTL, C., \& STRUNK, G. (2000). Towards a Habitus Based Concept of Managerial Careers. Paper presented at the Academy of Management, Toronto, Canada.

MAYRHOFER, W., STRUNK, G., SCHIFFINGER, M., IELLATCHITCH, A., STEYRER, J., \& MEYER, M. (2002). Career Habitus. Theoretical and Empirical Contributions to Make a Black Box Grey. Organisational Behaviour, 17(3), 548-596.

NORA, A. (2004). The role of habitus and cultural capital in choosing a college. Journal of Hispanic Higher Education, 3(2), 180-208.

PARSONS, T. (2013). Social system. New York: Routledge.

ROBBINS, D. (2005). The origins, early development and status of Bourdieu's concept of 'cultural capital'. The British journal of sociology, 56(1), 13-30.

SAVICKAS, M. L. (2005). The theory and practice of career construction. Career development and counseling: Putting theory and research to work, 1, 42-70.

SUUTARI, V., \& MÄKELÄ, K. (2007). The career capital of managers with global careers. Journal of Managerial Psychology, 22(7), 628-648.

VILHJÁLMSDÓTTIR, G., \& ARNKELSSON, G. B. (2013). Social aspects of career choice from the perspective of habitus theory. Journal of Vocational Behavior, 83(3), 581590.

WACQUANT, L. (2014). Homines in extremis: What fighting scholars teach us about habitus. Body \& Society, 20(2), 3-17.

ŽIŽEK, S. (2009). The parallax view. Boston: MIT Press. 